\title{
Cross-sectoral assessment of the performance gap using calibrated building energy performance simulation
}

Abstract: The energy performance gap in buildings is a well-known phenomenon. However, its actual definition and extent is dependent on the baseline used for defining the gap. In this paper a calibrationbased methodology is used to identify and validate the root causes of the performance gap. Following analysis of the performance of four case studies in the UK, from different building sectors, cross sectoral learnings that are applicable in the wider industry context are uncovered. Through the model calibration process and in the overall performance assessment, Indoor Environmental Quality (IEQ) parameters have been used to improve the robustness of validation of the calibrated models and to highlight the interrelationship of energy and IEQ. The study shows the importance of contractual accountability to minimise performance issues, building a case for having IEQ in energy performance contracts to manage the trade-offs of IEQ against energy performance that leads to unintended health consequences for the occupants.

Keywords: Energy Performance, Performance Gap, Model Calibration, Indoor Environment Quality

\subsection{Introduction}

The building sector has a high and cost-effective potential for providing long-term, energy and greenhouse gas emission savings (IEA, 2017). In the UK, the latest amendment of the Climate Change Act 2008 requires the UK to ensure net-zero carbon emissions by the year 2050 (HM Government, 2019). To achieve this target, various schemes have been implemented in the building sector. These schemes focus on improving energy efficiency and quantification of performance the design stage and during operations. While UK Building Regulations (Part L) and asset ratings (Energy Performance Certificates) focus on design stage quantification, the operational rating Display Energy Certificate scheme focuses on operational stage performance.

Building performance simulation tools can be used to calculate thermal loads and resulting energy use, along with related metrics for occupant comfort and Indoor Environmental Quality (IEQ). A good simulation model can deliver performance prediction with adequate level of accuracy, factoring in most of the complex physical interactions and interrelations (Judkoff, et al., 2008). However, evidence suggests that buildings underperform post-completion when compared against the performance predicted during the design stage. The difference between the actual energy use and the design intent is called the performance gap (Carbon Trust, 2012; de Wilde, 2014).

The performance gap is a commonly used terminology in the context of building energy use, but its definition is quite vague. Depending on the baseline chosen or the calculation protocols used, the magnitude and the cause of the gap can vary (Burman, 2016). Due to the assumptions used in defining the input parameters in design models, some variability in simulation outputs is to be expected. However, the scale of the discrepancy 
reported is very wide and reduces the confidence levels in the results of simulation tools (van Dronkelaar, et al., 2016). A calibrated computer model, which is a virtual representation of the actual building, can be used to investigate the performance issues and identify measures to fix them (Jain, et al., 2018).

In the context of the performance gap, energy performance is generally the most highlighted and emphasised. However, the gap is not just limited to energy, it also applies to the IEQ parameters. Moreover, the pursuit of energy efficiency may have the unintended consequence of compromising the IEQ, thereby requiring a holistic approach to performance assessment that includes IEQ (Shrubsole, et al., 2018).

The aim of this paper is to undertake a cross-sectoral examination of the performance gap in building energy use and its underlying root causes. A new method is developed and applied in four case studies, representing a large cross section of building types, to determine the performance gap and its causes. The method is based on a robust measurement and verification (M\&V) framework that is underpinned by building performance simulation and calibration. While centred on energy, the paper also highlights the unintended IEQ underperformance, which might occur when the focus of design is primarily to meet increasingly stringent energy efficiency objectives in new buildings.

One recently built building from each of the four categories, offices, schools, hospitals and apartment blocks, is selected in this study. Considered together, offices, schools and hospitals account for $46 \%$ of the nondomestic buildings in England and Wales and 37\% of the energy use (BEIS, 2016). Apartments account for $21 \%$ of the households in England and Wales (ONS, 2011). These represent a large proportion of the UK building stock and can provide insights into the endemic issues in the industry that drive the performance gap.

\subsection{Background}

\subsection{Performance prediction approaches and the energy performance gap}

As policies increasingly focus on creating low energy buildings and benchmarking their performances, the use of computer modelling has become essential to assess and improve performance throughout a building's life (Design, Construction, Operation, \& Retrofit). In most countries modelling is primarily undertaken for regulatory compliance and that type of modelling can be termed as compliance modelling (van Dronkelaar, et al., 2016 ). Under the EU Energy Performance of Buildings Directive (EPBD), in the UK's regulatory compliance systems, models are created to assess the energy performance for comparative assessments (DCLG, 2017). To calculate energy use, the compliance modelling approach followed in the UK uses standardised operating conditions, as per the UK National Calculation Methodology (NCM) (DCLG, 2017). These models often do not accurately reflect the building's actual operating conditions such as occupancy, temperature set points, and schedules of operation of HVAC systems. Furthermore, compliance modelling calculations in the UK do not 
report energy use related to equipment (plug loads). Compliance modelling calculations are suitable for policy application where there is a need for simplicity, replicability, verifiability and most importantly applicability for the entire building stock, and where 'relative' performance is important (e.g. comparing energy performance of a buildings against a reference building using the same method). However, these compliance calculation methods are sometimes inappropriately used to evaluate the energy use performance of buildings as discussed in CIBSE TM54 (CIBSE, 2013b) and Burman (2016). This happens due to the lack of understanding about the intentions, limitations and finer details of the calculations used, often resulting in misinterpreted prediction of actual performance (Jain, et al., 2018). Comparing actual energy use of a building with compliance modelling results, as per current UK Building Regulations which do not necessarily use real operation settings and do not report non-regulated energy (such as small power equipment) in building energy use totals, can inflate the performance gap and lead to a perceived gap (Burman, et al., 2014; van Dronkelaar, et al., 2016). To address this, CIBSE TM54 sets out a framework for projecting energy performance at the design stage. It allows designers to tailor the operating conditions as per the project brief and the predicted performance accounts for all end uses. In contrast with compliance modelling this approach is termed as performance modelling (van Dronkelaar, et al., 2016). The resultant gap between performance modelling calculation and the actual energy use might be termed as the actual gap. Figure 1 describes the calculation baselines and their relation to the various performance gaps.

Compliance Modelling Results: Results of regulatory compliance calculations that are often misinterpreted as a prediction of the actual performance.

Performance Modelling Results: Results of calculations done at the design stage that accounts for all end-uses and uses building specific inputs as per CIBSE TM54 or equivalent protocols.

Perceived Gap: The gap between the actual energy use and the often underestimated performance when compliance calculation results are misinterpreted as the predicted performance.

Actual Gap: Performance gap that is due to changes over time and the technical issues identified in the building and its systems.

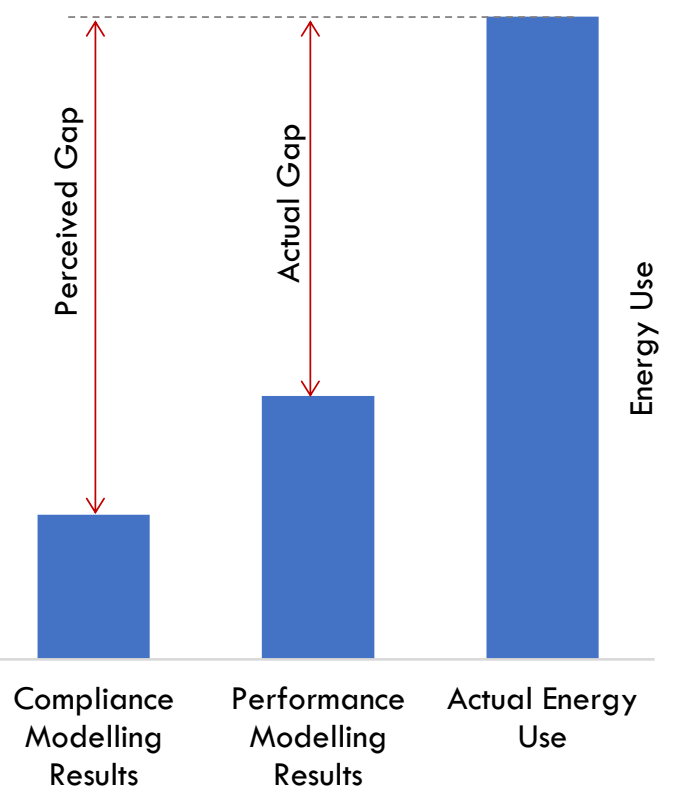

Figure 1: Performance calculations and associated gaps

CIBSE TM54 calculations are designed to deal with design stage issues. Problems during construction and operation stages, such as technical issues arising from poor workmanship or maintenance, or changes in 
building functions or occupancy trends over time can lead to underperformance but are not necessarily reflected in the model created using CIBSE TM54.

\subsection{Causes of the performance gap}

A key finding of the Post Occupancy Review of Building Engineering (PROBE) studies was that there was little connection between design assumptions and on-site observations (Bordass, et al., 2001a). The actual energy use of most buildings was almost twice the design estimates (Bordass, et al., 2001 a). The evidence from other countries corroborates this. A two-to-one discrepancy between actual and predicted energy performance in office buildings was identified in the US by Norfold et al. (1994). Studies on LEED certified buildings also revealed significant deviations in measured performance from the design projections (Turner \& Frankel, 2008; Samuelson, et al., 2014; Burman, 2016). Table 1 provides summary of the design and actual energy performance in the UK reported across the four case study building sectors. Being voluntarily provided data, the design calculations are not necessarily calculated in the same way for all the data, with some calculated with proper design assumptions and others based on regulatory compliance calculations. Nevertheless, because of the significant sample size, this data can be used to highlight the performance gaps indicatively.

Table 1: Design and actual energy performance for various building sectors in the UK

\begin{tabular}{|c|c|c|c|c|c|}
\hline \multirow[t]{2}{*}{ Sector } & \multicolumn{2}{|c|}{$\begin{array}{c}\text { Design* } \\
\mathrm{kWh} / \mathrm{m}^{2} / \mathrm{yr} .\end{array}$} & \multicolumn{2}{|c|}{$\begin{array}{c}\text { Actual } \\
\mathrm{kWh} / \mathrm{m}^{2} / \mathrm{yr} .\end{array}$} & \multirow[t]{2}{*}{ Source } \\
\hline & Gas & Elec. & Gas & Elec. & \\
\hline Office & 46 & 71 & 73 & 121 & $\begin{array}{l}\text { CarbonBuzz (Kimpian \& Chisholm, 2011) } \\
80 \text { design prediction \& } 113 \text { actual performance samples }\end{array}$ \\
\hline School & 57 & 56 & 84 & 106 & $\begin{array}{l}\text { CarbonBuzz (Kimpian \& Chisholm, 2011) } \\
133 \text { design prediction \& } 203 \text { actual performance samples }\end{array}$ \\
\hline Hospital & 317 & 122 & 373 & 143 & $\begin{array}{l}\text { (Morgensterna, et al., 2016) About } 150 \text { general acute hospital } \\
\text { samples. }\end{array}$ \\
\hline Apartment & 29 & 15 & 73 & 38 & $\begin{array}{l}\text { (Palmer, et al., 2016a) } 76 \text { homes. Source data is in } \\
\mathrm{kgCO}_{2} / \mathrm{m}^{2} / \mathrm{yr} \text {. Carbon intensity }\left(\mathrm{kgCO}_{2} / \mathrm{kWh}\right) \text { Gas } 0.194 ; \\
\text { electricity } 0.55\end{array}$ \\
\hline
\end{tabular}

* Sourced from voluntary platforms, some of the design performance within the sample maybe based on compliance modelling.

The performance gap can be due to many factors during design, construction and operation of buildings. Understanding of the causes of the gap is essential to maintain confidence in the performance estimates and the tools used for it. A review of 28 case studies in the UK found that $75 \%$ of the buildings underperformed due to serious shortcomings in construction practices, control strategies, commissioning, building fine-tuning in early stages of post-occupancy, user training, building management and maintenance (Carbon Trust, 2012; Shrubsole, et al., 2018). Another cross-sectoral study documented problems associated with building fabric, control strategies, commissioning, installed metering strategies and inadequate provision of training (Palmer, et al., $2016 \mathrm{~b})$. Table 2 describes the major causal factors identified for energy performance gap in previous studies. 
Table 2: Performance gap factors for various building stages

\begin{tabular}{|c|c|c|}
\hline Building stage & Performance Gap Factors & Source \\
\hline \multirow[t]{3}{*}{ Design } & $\begin{array}{l}\text { Design targets: energy may be poorly specified in project } \\
\text { briefing and in the design criteria and conflict with other targets } \\
\text { (e.g. energy efficiency vs. minimum air change rates). }\end{array}$ & $\begin{array}{l}\text { (Bordass, et al., 2001 a); } \\
\text { (Bannister, 2009) }\end{array}$ \\
\hline & $\begin{array}{l}\text { Design issues: recurring issues include specification of } \\
\text { centralised systems for local loads, HVAC system oversizing and } \\
\text { poor zoning, and poor control interface between low or zero } \\
\text { carbon technologies and backup systems. }\end{array}$ & $\begin{array}{l}\text { (Bordass, et al., 2001 a); } \\
\text { (Bannister, 2009); } \\
\text { (Burman, 2016) }\end{array}$ \\
\hline & $\begin{array}{l}\text { Modelling issues: the method used for energy performance } \\
\text { calculation, modelling uncertainty, software variability, and } \\
\text { variability in weather data and other model input along with } \\
\text { occupants can significantly impact the calculation accuracy. }\end{array}$ & $\begin{array}{l}\text { (Guyon, 1997); (Ahmad \& } \\
\text { Culp, 2006); (Wang, et } \\
\text { al., 2012); (Neymark, et } \\
\text { al., 2002) }\end{array}$ \\
\hline Construction & $\begin{array}{l}\text { Poor build quality: recurring issues include poor airtightness } \\
\text { and gaps in fabric insulation, thermal bridging at construction } \\
\text { junctions, and poor installation of building services such as the } \\
\text { air distribution systems in mechanically ventilated buildings. } \\
\text { Value engineering process: if key determinants of energy } \\
\text { performance are not protected, the value engineering process } \\
\text { may compromise the original design intent. }\end{array}$ & $\begin{array}{l}\text { (Bordass, et al., 2001 b); } \\
\text { (Petersen \& Hviid, 2012); } \\
\text { (Wingfield, et al., 2013); } \\
\text { (Bordass, et al., 2004) }\end{array}$ \\
\hline \multirow[t]{2}{*}{ Commissioning } & $\begin{array}{l}\text { Basic commissioning: major commissioning flaws can } \\
\text { compromise energy efficiency (e.g. incorrect equipment } \\
\text { installation and poor commissioning of controls). }\end{array}$ & $\begin{array}{l}\text { (Piette, et al., 1994); } \\
\text { (Bannister, 2009); (Pang, } \\
\text { et al., 2012); (ZCH, 2014) }\end{array}$ \\
\hline & $\begin{array}{l}\text { Lack of seasonal commissioning: in complex buildings, this can } \\
\text { be critical (e.g. naturally ventilated buildings with different } \\
\text { settings for heating season and summertime performance). }\end{array}$ & (Burman, 2016) \\
\hline \multirow[t]{2}{*}{ Handover } & $\begin{array}{l}\text { Inadequate training: effective training of building users } \\
\text { including key personnel such as facility managers is essential. }\end{array}$ & (Carbon Trust, 2012) \\
\hline & $\begin{array}{l}\text { Incomplete documentation: documents for building managers } \\
\text { with guidance for operation of the building and its systems (e.g. } \\
\text { operations and maintenance manuals and building logbooks). }\end{array}$ & (Palmer, et al., 2016b) \\
\hline \multirow[t]{3}{*}{ Operation } & $\begin{array}{l}\text { Lack of building fine-tuning: post-occupancy evaluation can } \\
\text { help identify and address performance issues. }\end{array}$ & (Menezes, et al., 2012) \\
\hline & $\begin{array}{l}\text { Occupant behaviour: it is a source for uncertainty at design } \\
\text { stages but also affects actual building operation. }\end{array}$ & $\begin{array}{l}\text { (Azar \& Menassa, 2012); } \\
\text { (Martani, et al., 2012) }\end{array}$ \\
\hline & $\begin{array}{l}\text { Poor maintenance: longitudinal performance of the building } \\
\text { including maintenance will impact on the performance gap. }\end{array}$ & $\begin{array}{l}\text { (Bannister, 2009); (de } \\
\text { Wilde \& Jones, 2014) }\end{array}$ \\
\hline
\end{tabular}

\subsection{Energy simulation, model calibration and its role in performance assessment}

Efforts have been made to improve the predictive capabilities of the simulation process by using better tools

(Andre, et al., 2008) and improving the understanding of building-occupant interactions (Haldi \& Robinson, 2008). While these efforts help to close the performance gap by making the performance modelling calculations more accurate, calibrating simulation models using monitored data has also been used to understand the performance issues that are the cause of the actual gap (Jain, et al., 2018).

A typical calibration process requires two sets of data. One is the simulation input data which is often based on the design values and the operational assumptions. This simulation input data is used to calculate the predicted performance. The other data set is the metered data from the monitoring of the real building. Depending on the objective of the calibration, the parameters affecting the specific outputs concerned are fine-tuned to create a suitable match between the simulated performance and the monitored data. 
To develop calibrated model for diagnosing performance gap issues, a step by step, evidence-based calibration methodology should be followed which is procedural and replicable (Reddy \& Maor, 2006; Raftery, et al., 2011 ; Bertagnolio, et al., 2012). The minimum monitored data needed for any energy use calibration is the operational consumption for all fuels for a period of at least one year (ASHRAE, 2014). More detailed monitored data including disaggregated end-use energy consumption provides an opportunity for finer calibration and thereby increasing accuracy and confidence in the simulation model (EVO, 2016). Monitoring of IEQ data streams can also provide evidence for detailed operational profiles. Temperature data can provide evidence of zone set-point temperature. Similarly, $\mathrm{CO}_{2}$ and $\mathrm{PM}_{2.5}$ concentrations can provide details about occupancy patters, ventilation and infiltration rates (Kapalo, 2013; Parsons, 2014; Batterman, 2017). Calibration can give insights into the operational inefficiencies and pinpoint underlying causes for the performance gap (Burman, 2016). Subsequently, a calibrated model could be used for detailed analysis by reintroducing design assumptions and quantify impacts of the underlying causes on performance.

\subsection{Going beyond the energy performance gap}

Energy efficiency is a key objective for new buildings and major renovations and the debate about the performance gap has raised awareness about the need of meeting the energy performance goals in practice. However, this is not necessarily the case for IEQ parameters - IEQ has only come to prominence relatively recently. This can be seen in the changes in the revised version of the EPBD (EPBD 2018/844). The original EPBD (EPBD 2010/31/EU) focused on reducing energy use. The revised EPBD highlights the importance of health, comfort, indoor air quality (IAQ) and indoor climate. However, details about their practical implementation are yet to be addressed (Council Directive, 2018). In current practice, while adhering to IEQ standards is an essential aspect during design, the actual performance post-construction is not usually evaluated. Similar to the performance gap in energy use, the underperformance can also be seen in IEQ parameters such as temperature, air quality (pollutants, $\mathrm{CO}_{2}$ ), noise and lighting (Tuohy \& Murphy, 2015; Fabbri \& Tronchin, 2015; Phillips \& Levin, 2015). Moreover, the ways to achieve better IEQ and building user satisfaction might contradict with the measures to achieve better energy performance. Therefore, if the focus is only on energy or on carbon emissions, this can lead to the unintended consequence of poor IEQ in buildings. Energy use reduction is not enough unless it allows the buildings to perform their desired functions i.e. to be healthy, comfortable and productive places to live and work in (Jain, et al., 2017).

An example of these conflicts is the overheating and air quality issues that are uncovered in some new buildings which are constructed to higher energy standards with high insulation and airtightness (Logue, et al., 2011 ; Larsen, et al., 2012 ; Maivel, et al., 2015; Abadie \& Wargocki, 2016). CO 2 concentrations are often 
used as a proxy for IAQ. However, in urban areas, traffic-related external pollutants such as fine Particulate Matter (PM2.5) and $\mathrm{NO}_{2}$ are linked to adverse health impacts and can potentially compromise IAQ (AQEG, 2004; AQEG, 2005). This may have significant implications where ventilation strategies are adopted that improve energy efficiency but don't necessarily address outdoor pollution. Therefore, a holistic energy and environmental performance approach is necessary to understand the intricate interrelationship between these performance aspects to avoid unintended consequences and address gaps in the performance.

\section{$\underline{2.5}$ Measurement and verification $(M \& V)$ and calibrated model validation approaches}

$M \& V$ is the process in which planning, measuring, collecting, and analysing of data is undertaken for verifying and reporting a building's performance. M\&V protocols such as ASHRAE Guideline 14 (ASHRAE, 2014) and IPMVP (EVO, 2016) generally focus on quantitative requirements and are not tied in a framework for a procedural verification of all issues. Therefore, it is not certain that the technical issues uncovered in a building through, e.g. onsite investigations, reflect all or most of the key causes of the performance gap. It is likely that some key issues are identified during the investigations whilst other potential issues are not uncovered.

ASHRAE Guideline 14 and IPMVP recommend model calibration as a M\&V option and provide validation criteria for checking the accuracy of the calibrated models. The validation criteria consist of two statistical indices, Coefficient of variation of the Root Mean Square Error (Cv(RMSE)) and Normalised Mean Bias Error (NMBE). However, if the operational information is limited, it is not possible to procedurally evaluate, with high confidence, the value of inputs that can create a calibrated model. Some of the solutions might be mathematically correct but physically impossible to achieve. If the operation stage information is limited, then the modeller needs to rely on their engineering judgement and use these judgements about potential issues in dynamic thermal simulation to meet the criteria and cross-validate them from the site.

CV(RMSE) and NMBE criteria are necessary but they may not be sufficient to check for calibration in some cases because by using only these indices it may not possible to accurately match the highly dynamic behaviour of a building at small time-steps (Garrett \& New, 2016; Ruiz \& Bandera, 2017). Therefore, besides these statistical indices, graphical techniques such as hourly loads profiles, box-whisker-mean plots, 3-D surface plots along with disaggregated end uses, peak load checks and zone temperatures (EVO, 2016) can also be used to assess the success of calibration. As a minimum, it is important to show that in addition to meeting the statistical calibration criteria for energy use, there is sufficient accuracy for other dependent parameters, such as the room temperatures (Royapoor \& Roskilly, 2015; Roberti, et al., 2015). For temperature checks, the $\mathrm{CV}(\mathrm{RMSE})$ and NMBE criteria for energy in ASHRAE Guideline 14 might not be suitable. Indoor temperatures vary within a small range and ASHRAE Guideline 14 acceptance limits can lead to an inclusion of large 
deviations from the comfort bands. There are no standards or formal guidelines that define acceptance criteria for zone air temperatures calibration. Being relative statistical indices, CV(RMSE) and NMBE are scale dependent and can lead to high variation in temperatures if the same limits applied to energy performance is used to check model calibration for temperatures. Statistical indices that address absolute errors such as Mean Absolute Error (MAE) and Root Mean Square Error (RMSE) was used by Roberti, et al. (2015). These are also used in climate research (Chai \& Draxler, 2014). In most studies acceptable absolute error was in the range of $\pm 1-2^{\circ} \mathrm{C}$ for most of the temperature data points (Booten \& Tabares-Velasco, 2012; Royapoor \& Roskilly, 2015; Ruiz, et al., 2016; Beizaee, 2016). MAE of $1^{\circ} \mathrm{C}$ and RMSE of $1.5^{\circ} \mathrm{C}$ can be used as reasonable targets for air temperature calibration check.

\subsection{Gap in knowledge}

The evidence from existing studies show performance issues for both energy and IEQ. Most design energy calculations are carried out in the context of compliance modelling. Performance modelling using the CIBSE TM54 methodology makes simulation results more representative of actual performance at the design stage. However, if applied to buildings in-use during $M \& V$, it does not provide a method to separate discrepancies in the operational settings and functional use changes that have evolved over time from the technical issues. Therefore, it may not give a full picture of any performance gap and its underlying causes (issues related to construction, commissioning and operations). Using energy model calibration as a tool for performance gap assessment is a useful approach to identify, quantify and validate the performance issues in buildings.

\subsection{Methodology:}

A robust $M \& V$ framework aiming to close the performance gap should identify and separate:

i. Deviations of operating conditions from design that are driven by the building's function and occupancy,

ii. Technical issues that cause a performance gap between the design intent and the actual operation.

This process can be achieved by making dynamic thermal simulation and model calibration integral to $M \& V$. This paper uses a systematic calibration-assisted method to find and validate the building level performance issues, identifying deviations in operating conditions as well as technical issues separately. The process starts with collecting data and comparing actual data against the design information to quantify the magnitude of the gap and to identify discrepancies in the two datasets. Next, a design model is created using the design data and is then calibrated using evidence based fine-tuning as per the operation stage information to match to the metered data. The calibrated model's energy results are validated through standard statistical checks ( $C v(R M S E)$ and NMBE) and further cross-validated by checking the zone temperatures predicted by the model against the monitored data. The identified changes in the building, its systems and overall operations, that 
are verified during site investigations and had led to the creation of the calibrated model are assumed to be the key factors causing the gap. In the final stage, an operational baseline is created and the gap due to technical issues is calculated by reverting the technical changes in the calibrated model to their design intents.

Figure 2 explains the operational baseline and the two types of gap that constitute the actual gap.

Building on the categorisation of the gaps in Figure 1, the actual gap can be further categorised into gaps due to

- Changes in operational requirements: Modifications mode in the building or its systems to meet its changed operational needs to ensure that the building can perform its function in practice.

- Technical issues: Shortcomings and unintended changes with the building and its design, its systems and their operations and maintenance that can cause underperformance.

Operational Baseline: A revised baseline from a model which reflects actual operating conditions (that may have changed over time due to functional needs) but still has the original technical design intents.

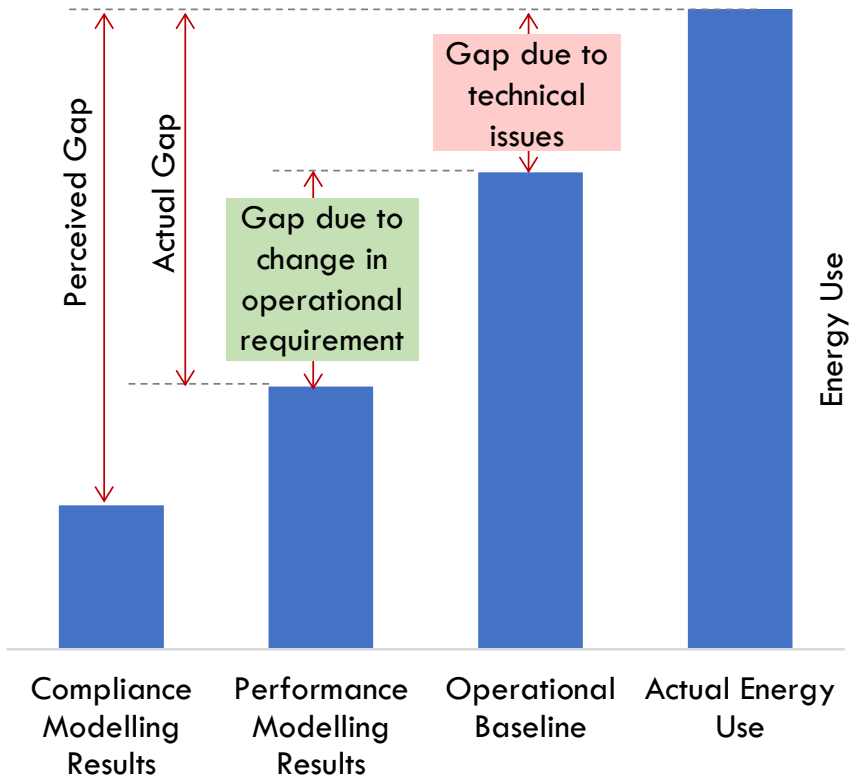

Figure 2: Building on Figure 1, new operational baseline based on the actual gap categorisations

Applying this process across the case study buildings provides lessons that may also be applicable across the building sector along with an understanding of model calibration issues and unintended consequences on IEQ.

The method is explained in greater detail below and diagrammatically presented in Figure 3. 


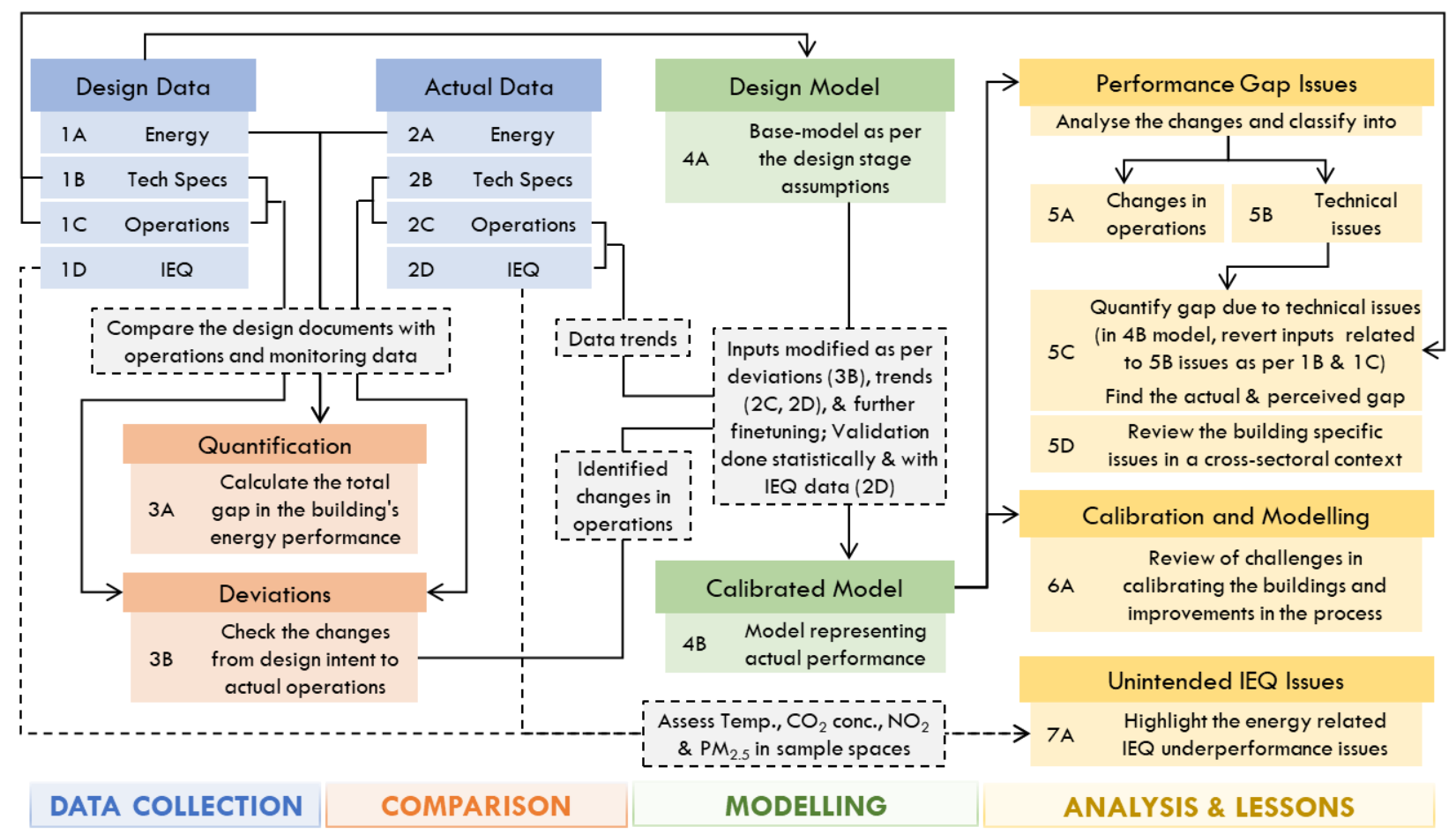

Figure 3: Methodology for performance gap assessment using calibrated energy simulation

\subsection{Data collection}

First, the building's design intents, and actual data were collected. Design data was collected from the design documents with details about the energy (1A) and IEQ (1D) targets, technical specifications of building systems (1B) and building operational parameters (1C). Actual data was collected during site-visits, recording metered energy use $(2 A)$ and documenting building technical and operational details $(2 B / 2 C)$. The actual IEQ performance (2D) was captured through regular monitoring of typical zones for Temperature, $\mathrm{CO}_{2}$ concentrations (a proxy for fresh air), $\mathrm{NO}_{2}$ (primarily a traffic driven pollutant) and $\mathrm{PM}_{2.5}$.

\subsection{Comparison}

Design intended energy performance was then compared with the actual measured monthly energy use to quantify the magnitude of the performance gap (3A). Comparing the technical specifications and operations of the building and systems also gives insight into possible operational stage deviations (3B).

\subsection{Modelling}

In the next stage, an initial design model (4A) was created using DesignBuilder V6.0 (DesignBuillder Software Ltd., 2019) based on the design data. This design model was then modified in accordance with actual operations (2C) and IEQ measurements (2D); and operational stage deviations (3B). Further calibration was undertaken by evidence-based manual fine-tuning of various input parameters. Actual weather as per station and satellite measurements for relevant location for the calibration period was obtained from DesignBuilder 
Climate Analytics tool (DesignBuilder Software Ltd., 2019) and was used in the simulations. The calibrated model (4B) was validated using the monthly calibration criteria of ASHRAE Guideline 14 (Cv(RMSE) < 15\%; NMBE $< \pm 5 \%$. Also, hourly temperatures for typical weeks were compared against measured values (2D) in a sample space (Criteria used: $M A E<1{ }^{\circ} \mathrm{C}, \mathrm{RMSE}<1.5^{\circ} \mathrm{C}$ ). The intention of this stage is that once the calibrated model is created and validated then the deviations that were identified in $3 B$ are considered to be verified.

\subsection{Analysis and Lessons}

The classification shown in Figure 2 is used to assess each building's performance. The deviations in 3B (and their potential causes) in relation to building's use, operation settings, systems' functioning and controls were classified into the differences that were due to change in operational requirement $(5 \mathrm{~A})$ and those due to technical issues (5B). The classification is done as per building performance evaluations and based on the understanding of the building characteristics. The deviations in operating conditions related to the changes in building function or occupancy and required by the building to perform its functions in practice were classified into $5 \mathrm{~A}$, whereas all the technical and technological shortcomings into $5 \mathrm{~B}$. Subsequently, to quantify the performance gap due to technical issues (5C) only, deviations relating to technical issues (5B) were reverted to their design intents as per IB and IC to create an operational baseline. This baseline reflected the actual operating conditions (such as modified space-time use of the building and its systems) needed by the building to perform its functions in practice but assumed the original design technical specification. Comparing the actual energy use with this baseline determines the actual energy performance gap arising from technical issues. After analysing all four case study buildings, common performance issues were identified and then used to suggest some remedies that can impact a large cross-section of the building stock (5D). Besides this, general lessons relating to model calibration and validation of results were identified (6A). The findings from IEQ data showing underperformance issues and conflicts related with energy objectives were also reported (7A).

\section{$\underline{4.0 \text { Case Study Buildings }}$}

\subsection{Summary of Building Characteristics}

The case studies are typical examples of newly built buildings in their respective sectors. Table 3 describes their key information and Table 4 explains their design-stage construction and operational characteristics. 
Table 3: Key information about case study buildings

\begin{tabular}{|l|c|c|c|l|}
\hline Building & Location & $\begin{array}{c}\text { Useful Floor } \\
\text { Area }\left(\mathrm{m}^{2}\right)\end{array}$ & $\begin{array}{c}\text { Date } \\
\text { Completed }\end{array}$ & \multicolumn{1}{c|}{ Remarks } \\
\hline Office & $\begin{array}{c}\text { Somerset } \\
\text { (Keynsham) }\end{array}$ & 6,363 & 2014 & $\begin{array}{l}\text { Open plan office with meeting rooms; four floors } \\
\text { with narrow floor plates which are inter-connected } \\
\text { by atriums and cut-outs } \\
\text { - Project procured under an Energy Performance } \\
\text { Contract and within a Soft-Landings framework } \\
\text { (Way, et al., 2009) }\end{array}$ \\
\hline School & $\begin{array}{l}\text { London } \\
\text { (Wandsworth) }\end{array}$ & 21,405 & 2014 & $\begin{array}{l}\text { - Secondary school \& sixth form with academy status } \\
\text { - Eight campus buildings with four floors each } \\
\text { - Performance analysis at the campus level with } \\
\text { detailed assessment of one building }\end{array}$ \\
\hline Hospital & $\begin{array}{c}\text { Bristol } \\
\text { (City Centre) }\end{array}$ & 16,122 & 2015 & $\begin{array}{l}\text { - Patient ward building in a hospital campus; 'Acute' } \\
\text { type hospital (as defined in ECG72 (BRECSU, 1996)) } \\
\text { Nine floors; spaces include wards, consulting rooms, } \\
\text { offices, diagnostics, operating theatres, a canteen } \\
\text { and the usual amenity rooms. }\end{array}$ \\
\hline $\begin{array}{l}\text { Apartment } \\
\text { Block }\end{array}$ & $\begin{array}{l}\text { London } \\
\text { (Tower } \\
\text { Hamlets) }\end{array}$ & 7,940 & 2015 & $\begin{array}{l}\text { - Block with 98 flats across two buildings. } \\
\text { - Performance analysis at the block level with detailed } \\
\text { assessment of a typical flat }\end{array}$ \\
\hline
\end{tabular}

Table 4: Design-stage construction and operation characteristics of case study buildings

\begin{tabular}{|c|c|c|c|c|c|c|}
\hline Building & \multicolumn{6}{|l|}{ Details } \\
\hline \multirow{7}{*}{ Office } & Fabric & \multicolumn{2}{|c|}{$\begin{array}{r}\mathrm{U}-\text { Value }\left(\mathrm{W} / \mathrm{m}^{2} \mathrm{~K}\right) \\
\text { Wall: } 0.20 \\
\text { Window: } 1.40 \\
\text { Roof: } 0.15 \\
\text { Ground: } 0.15 \\
\end{array}$} & $\begin{array}{c}\text { Airtightness } \\
5 \mathrm{~m}^{3} / \mathrm{hr} / \mathrm{m}^{2} @ 50 \mathrm{~Pa}\end{array}$ & \multicolumn{2}{|c|}{$\begin{array}{c}\text { Remarks: High insulation, } \\
\text { Passive design, exposed } \\
\text { thermal mass }\end{array}$} \\
\hline & & \multicolumn{2}{|c|}{ Heating and Hot Water } & Cooling & \multicolumn{2}{|c|}{ Ventilation } \\
\hline & $\begin{array}{l}\text { HVAC } \\
\text { system }\end{array}$ & \multicolumn{2}{|c|}{$\begin{array}{l}\text { Provided by heat pumps } \\
\text { with gas-fired boilers for } \\
\text { additional need \& as a } \\
\text { backup. Supplied in the } \\
\text { spaces by radiators. } \\
\text { Controlled centrally. }\end{array}$} & $\begin{array}{l}\text { Provided by heat pumps } \\
\text { and supplied by chilled } \\
\text { beams in meeting rooms \& } \\
\text { areas with high ICT only. } \\
\text { Backup chiller for server } \\
\text { room. Controlled centrally. }\end{array}$ & \multicolumn{2}{|c|}{$\begin{array}{l}\text { Natural only, supplied by } \\
\text { automatic vents which are } \\
\text { controlled based on } \mathrm{CO}_{2} \\
\text { levels and temperature. } \\
\text { Manually operable vents } \\
\text { also provided. }\end{array}$} \\
\hline & Lighting & \multicolumn{5}{|c|}{$\begin{array}{l}\text { - Energy efficient background (LED, T16 lamps) and task lighting (CFL) scheme } \\
\text { - Controls include Passive Infra-Red (PIR) and daylight sensors. }\end{array}$} \\
\hline & \multirow[b]{2}{*}{ Operations } & Occupants & \multicolumn{3}{|c|}{ Occupancy Schedule } & Setpoints \\
\hline & & 455 persons & $\begin{array}{l}\text { Weekday } \\
\text { some out }\end{array}$ & $\begin{array}{l}\text { ys: } 0700 \text { - } 1900 \text { with divers } \\
\text { of hours' occupancy; Weeke }\end{array}$ & $\begin{array}{l}\text { sity and } \\
\text { ends: } \text { nil. }\end{array}$ & $\begin{array}{l}\text { Heating: } 19{ }^{\circ} \mathrm{C} \\
\text { Cooling: } 23^{\circ} \mathrm{C}\end{array}$ \\
\hline & Metering & \multicolumn{5}{|c|}{$\begin{array}{l}\text { - Separate meters for all systems and end-uses to record the disaggregated } \\
\text { energy use in high resolution, separated as per floor and/or cluster of zones }\end{array}$} \\
\hline \multirow[t]{2}{*}{ School } & Fabric & \multicolumn{2}{|c|}{$\begin{aligned} & U-\text { Value }\left(\mathrm{W} / \mathrm{m}^{2} \mathrm{~K}\right) \\
& \text { Wall: } 0.17 \\
& \text { Window: } 1.63 \\
& \text { Roof: } 0.20 \\
& \text { Ground: } 0.15\end{aligned}$} & $\begin{array}{c}\text { Airtightness } \\
5 \mathrm{~m}^{3} / \mathrm{hr} / \mathrm{m}^{2} @ 50 \mathrm{~Pa}\end{array}$ & \multicolumn{2}{|c|}{$\begin{array}{l}\text { Remarks: Envelope is } \\
\text { made of prefabricated } \\
\text { concrete panels, } \\
\text { assembled at the site; } \\
\text { high thermal mass }\end{array}$} \\
\hline & & \multicolumn{2}{|c|}{ Heating and Hot Water } & Cooling & \multicolumn{2}{|r|}{ Ventilation } \\
\hline
\end{tabular}




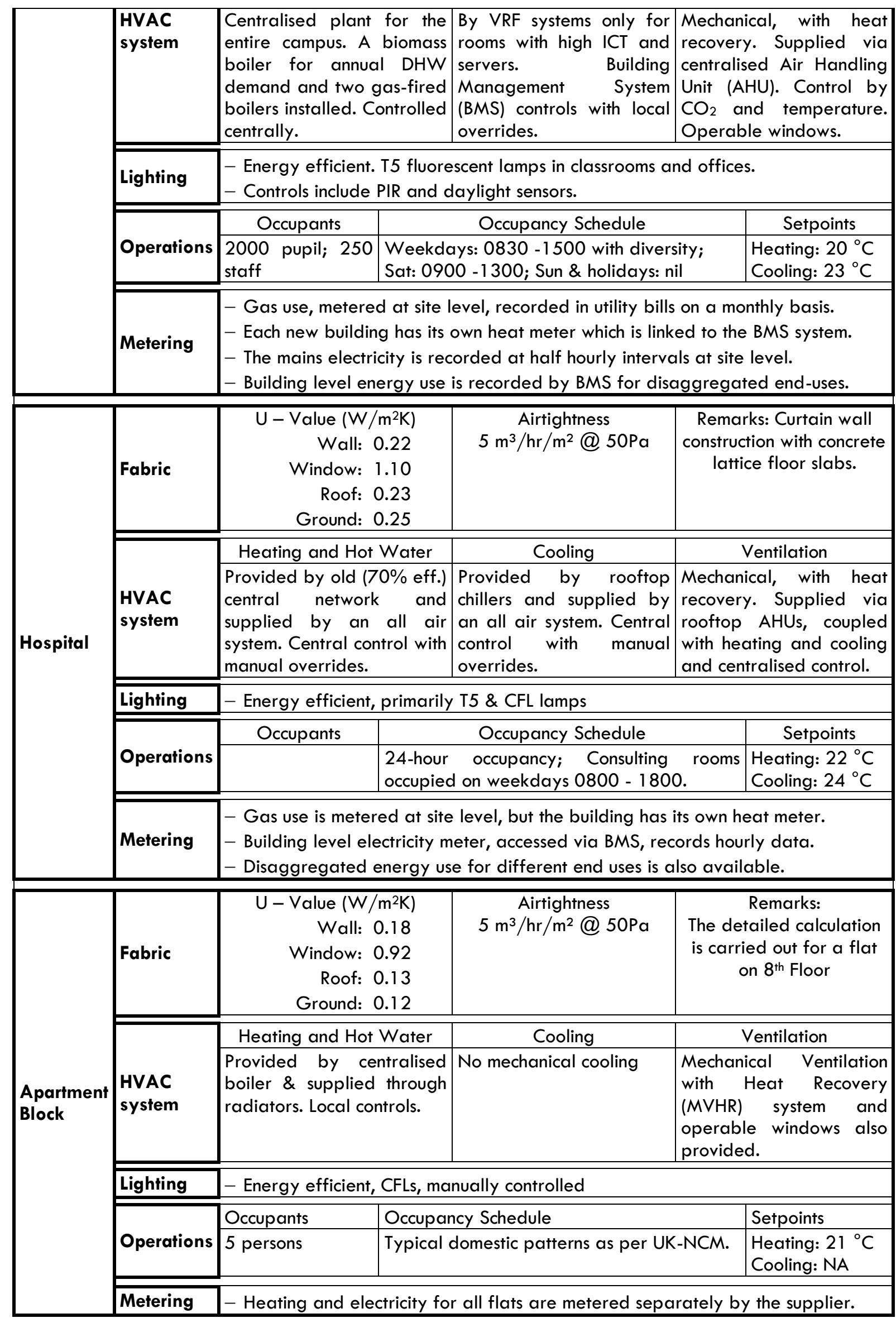


\begin{tabular}{|l|l|}
\hline & $\begin{array}{l}\text { Readings (sometimes partly interpolated/extrapolated for electricity) are } \\
\text { available at monthly and daily resolutions. }\end{array}$ \\
\hline
\end{tabular}

4.2 Comparison of design stage (compliance/performance modelling) results vs actual energy use

Figure 4 shows the annual design stage (compliance/performance modelling calculation) energy use results and the actual energy use, comparing it with UK good practice benchmarks. The monthly breakdown of energy use for all the case study buildings is also shown. We discuss these numbers for each building below and point out key issues found during initial observations.

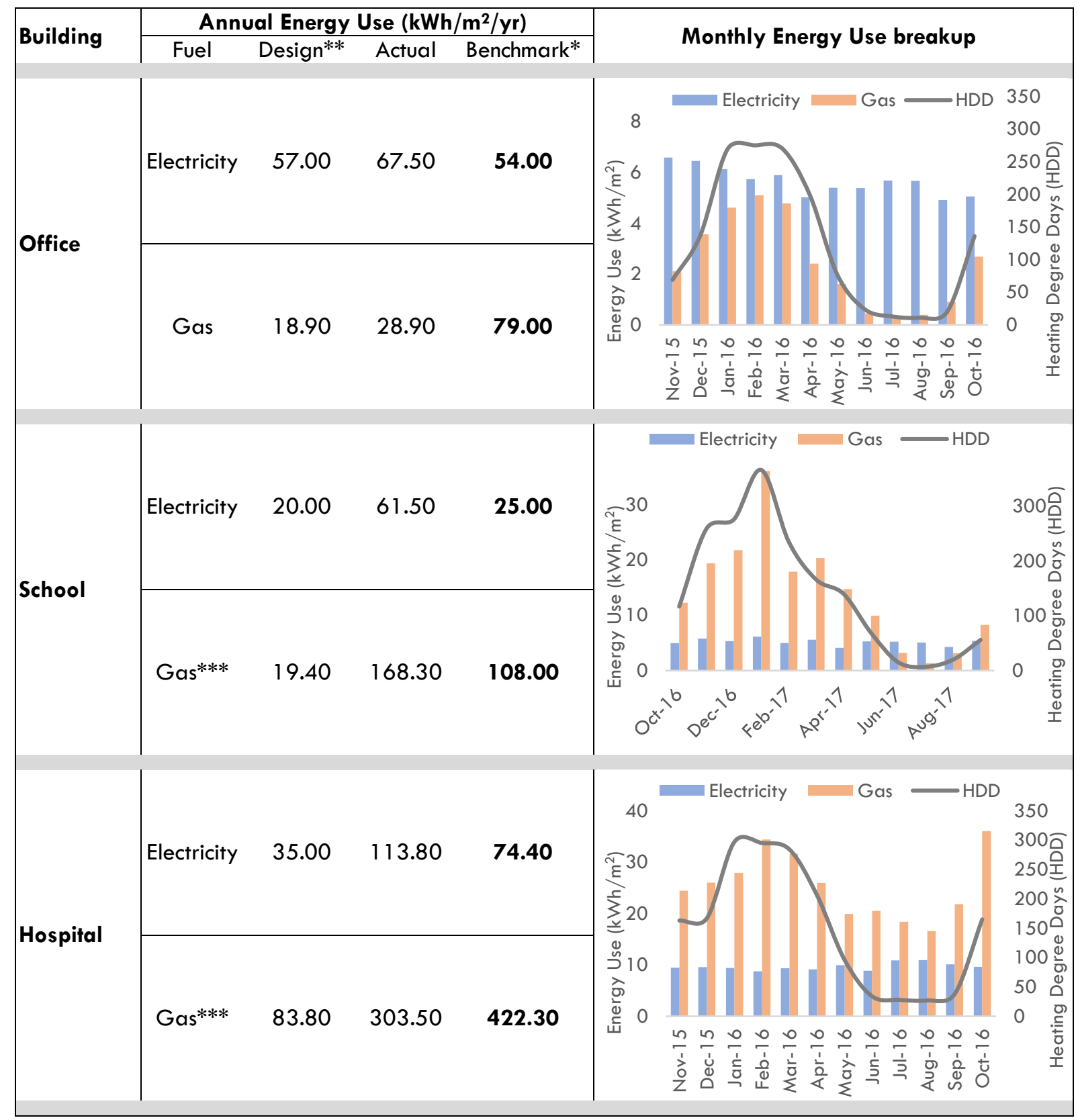




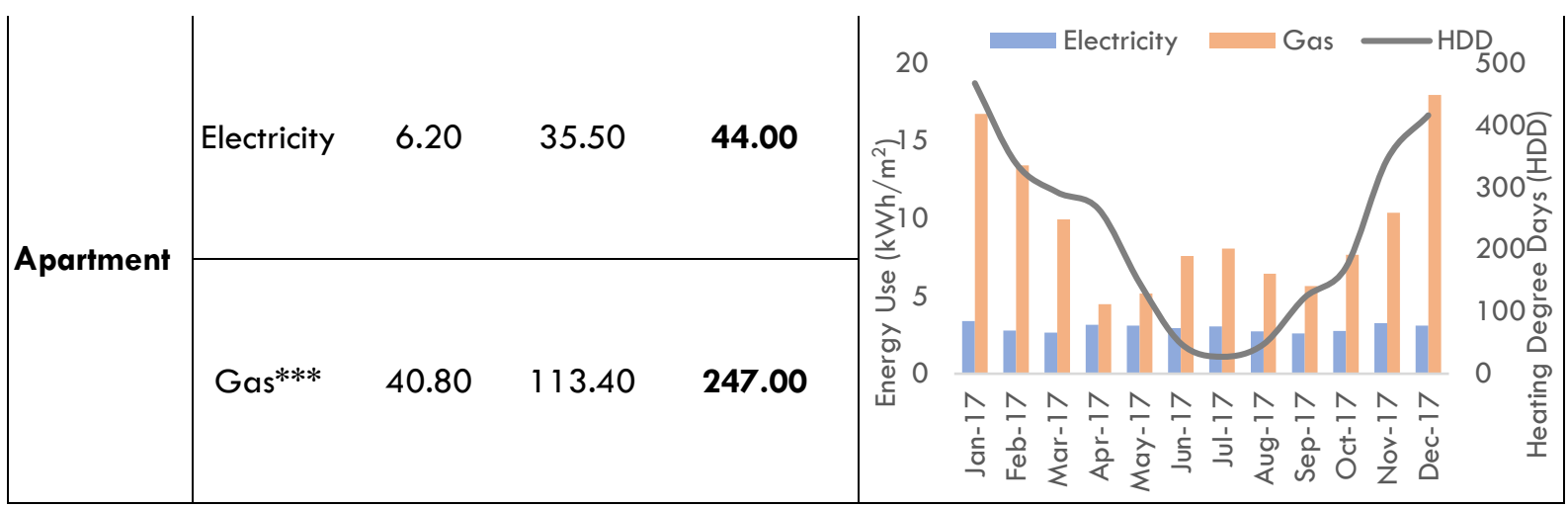

* Good practice benchmark as per CIBSE Guide F (CIBSE, 2012); ** In the school, hospital and apartment design values are based on compliance modelling and do not report equipment energy, the office design values are based on performance modelling; *** Heat/Gas provided by a district system, the numbers are adjusted for the system's gross seasonal efficiency.

Figure 4: Annual and monthly energy use comparison

Office: The building was procured under an energy performance contract within the Soft Landings Framework (Way, et al., 2009). The design team, since project inception, regularly tracked the impact of their design decisions on energy used with the intention of ensuring that the very low energy use performance targets of the building could be met. However, Figure 4 shows that the actual performance, two years after building handover was not at the desired levels. The design calculations, during concept design phase, determined the performance targets. These targets went beyond the restrictions of regulatory compliance calculations. The actual data was collected from the sub-meters installed on site. Initial observations suggested that some of the increase in gas use is because the heat pumps, designed to use rejected heat from the servers to heat the building, had technical problems. Consequently, the gas-fired boilers provided all the heating. In spite of this gap, due to the stringency of the targets and the use of performance contracting, the building's actual performance compares favourably against the good practice benchmark (CIBSE, 2012) for naturallyventilated public office buildings in the UK.

School: There are eight buildings on the campus. During the campus's redevelopment, six new buildings were constructed, and two existing ones were refurbished. Along with an overall campus level assessment, detailed performance issues were assessed in one of the teaching buildings.

The school was installed with a biomass boiler to reduce its gas use and minimise carbon emissions. The design stage projections were taken from the calculations done as a part of the UK Building Regulations (Part L) compliance. The actual performance was recorded from the Building Management System (BMS). A significant underestimation of energy use of the teaching building is shown in Figure 4, mainly because design regulatory calculations were used as design projections. Despite being a new building, gas and electricity use is 1.5 times and 2.5 times more respectively, when compared to the good practice benchmarks (CIBSE, 2012). 
Some of the deviation could be because the biomass boiler installed was not used due to logistic issues of handling of the biomass. Also, site observations suggested that building was occupied after school hours and during half-term breaks and school holidays.

Hospital: This building is a new ward complex built within an existing campus and is classified as an "acute hospital' (BRECSU, 1996). The design stage projection of energy performance was done as a part of UK Building Regulations (Part L) compliance. The actual electricity use was obtained from the BMS.

The energy use projection in Figure 4 differs from the actual use significantly. Besides the perceived gap issue, one of the main reasons for underestimation of the gas use is ongoing use of the low efficiency district heating system, which, as per design intent, was to be replaced by a new high efficiency Combined Heat and Power (CHP) system. Furthermore, monthly trends show a significant gas use during the non-heating periods (JunSep). This base demand is primarily for hot water use, which in hospitals in the UK has been reported to constitute a significant proportion of total energy use (DECC, 2018 ).

Apartment: The apartment block consists of 98 flats across two towers. Performance issues were assessed for the entire apartment block with a detailed investigation of a typical flat. Figure 5 shows the spread of energy use in all flats. The typical flat selected for detailed analysis and calibration has energy use near the average value across the flats in the apartment block.

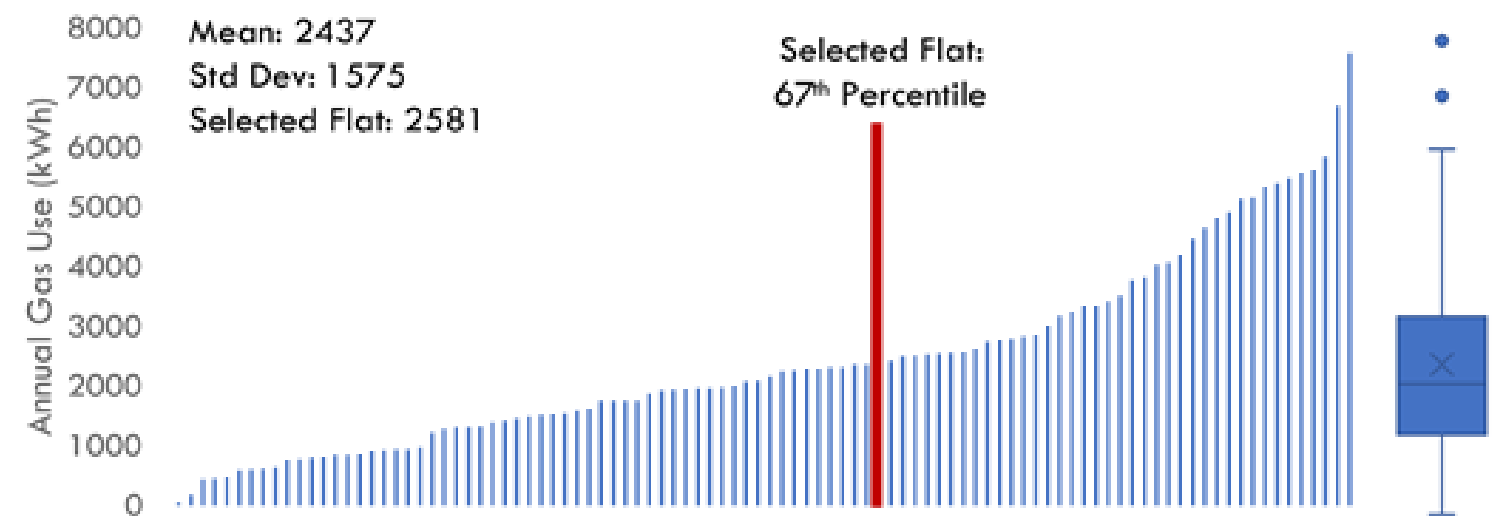

Figure 5: Spread of actual gas use of all the flats in the apartment block. (Red line highlights the energy use of the typical flat that was selected for detailed assessment.)

The design performance was calculated for building regulation compliance whereas the actual monthly gas and electricity use were obtained from the utility bills. Figure 4 shows that while actual gas use was marginally more than the design estimates, the actual electricity use had much more deviation because the equipment energy use was not reported in the total energy use in the design calculation.

In the monthly energy use data, reduction in heat demand in April and May and increase in Jun and July can be attributed to change in occupancy (such as holidays and guests) and other epistemic uncertainties of 
occupant behaviour such as opening of windows in summer months. These can be explored further and validated using calibrated models.

\subsection{Key performance issues identified and reasons for the performance gap}

Some of the possible operational stage deviations areas, observed during the data comparison stage (3B in

Figure 3) were further fine-tuned (along with identification of more issues) during the calibration stage to create a calibrated model (4B in Figure 3). The calibration process validated the identified issues by ensuring that the changes made in the calibrated model can account for most of the performance gap. Analysing the deviation of the model input parameters in this calibrated model against the as-design model, the key performance gap issues were listed. Then based on engineering judgement, these issues were categorised as per their root causes into either those related to changes in operational requirements or those arising from technical issues. Table 5 lists all the factors responsible for building underperformance that were validated through model calibration. The classification of the factors into changes in operational requirement and technical issues are undertaken as part of performance gap assessment (5A and 5B in Figure 3). However, for brevity, these have been shown in conjunction with the parameters changed for calibrated model (4B in

Figure 3). Figure 6 shows calibrated simulation results with their statistical error values.

Table 5: Operational and technical factors responsible for building underperformance

\begin{tabular}{|c|c|c|}
\hline Building & Changes in operational requirement & Technical Issues \\
\hline Office & $\begin{array}{l}\text { - The total occupancy of the building was about } \\
25-30 \% \text { higher, leading to more workstations } \\
\text { being added. } \\
\text { - Extended operation hours led to longer use of } \\
\text { small power and lighting. } \\
\text { - Heating set-point temperatures maintained } \\
\text { were about } 2^{\circ} \mathrm{C} \text { higher than the design } \\
\text { intention, driven primarily by occupant needs. } \\
\text { - Hot desking, using thin-client IT system, by } \\
\text { using flexible workstations was not followed in } \\
\text { practice. Departmental structure of the } \\
\text { occupant organisation restricted movement. } \\
\text { Therefore, hydraulic isolation of heating and } \\
\text { cooling systems in unoccupied zones during } \\
\text { out-of-hours use of the building could not be } \\
\text { followed. }\end{array}$ & $\begin{array}{l}\text { - Technical issues with heat exchangers and } \\
\text { the flow rates specification caused the heat } \\
\text { pumps to malfunction. } \\
\text { - Heating terminal's sizing was not consistent } \\
\text { with the low temperature flow required for } \\
\text { energy efficient operation of the system. } \\
\text { - Server loads were overestimated in design. } \\
\text { This adversely impacted the heating system } \\
\text { efficiency as there was less free heat. } \\
\text { - Overriding of automatic vent opening to } \\
\text { avoid thermal discomfort due to drafts } \\
\text { around the floors cut-outs. } \\
\text { - Some of the ventilation control sensor } \\
\text { malfunctioned and required a subsequent } \\
\text { modification to the control strategy to } \\
\text { overcome the system shortcomings. } \\
\text { - Parasitic loads were identified when the } \\
\text { building was unoccupied. }\end{array}$ \\
\hline School & $\begin{array}{l}\text { - All spaces were not occupied throughout the } \\
\text { day. Any given space is occupied only } 60 \text { - } \\
70 \% \text { of full working day. } \\
\text { - During academic breaks the school is not } \\
\text { completely shut. There are extra-curricular }\end{array}$ & $\begin{array}{l}\text { - Biomass boiler, installed for decarbonising } \\
\text { energy use, was never used, citing practical } \\
\text { and logistic issues of using biomass as fuel. }\end{array}$ \\
\hline
\end{tabular}




\begin{tabular}{|c|c|c|}
\hline & $\begin{array}{l}\text { activities and events, especially during the } \\
\text { summer holidays. } \\
\text { - Indoor temperatures monitored during the } \\
\text { winter season were about } 2^{\circ} \mathrm{C} \text { higher than the } \\
\text { set-point temperatures and sometimes even } \\
\text { more. }\end{array}$ & $\begin{array}{l}\text { - The Specific Fan Power in the AHU } \\
\text { commissioning sheets was } 66 \% \text { higher than } \\
\text { the values used in design stage estimations. } \\
\text { - Building heating and ventilation systems } \\
\text { were operating during unoccupied hours. } \\
\text { - The supply fan during unoccupied times was } \\
\text { running inefficiently, operating at } 30 \% \text { to } \\
40 \% \text { of its nominal speed. } \\
\text { - Centralised system design (one control and } \\
\text { sensor for multiple zones) led to inefficient } \\
\text { operations during out-of-hours use. } \\
\text { - Daylight sensors for automatic dimming of } \\
\text { lights were poorly commissioned and PIR } \\
\text { sensors had very long delay times. } \\
\text { - Actual boiler efficiency (tested) was } 88 \% \\
\text { compared to design intent of } 96 \% \text {. } \\
\text { - Significant thermal bypasses around } \\
\text { insulation was observed as the tested U- } \\
\text { values were much higher than the design. }\end{array}$ \\
\hline Hospital & $\begin{array}{l}\text { - Different clinical processes had different } \\
\text { needs. It was difficult to generalise typical } \\
\text { operational trends of various spaces; their } \\
\text { equipment loads; and set-point temperatures. } \\
\text { - Increased number of beds were observed in } \\
\text { patient wards during the site visits. } \\
\text { - Hospitals had a high changeover rate of } \\
\text { patients. Therefore, epistemic uncertainties in } \\
\text { set-point temperatures and operations of } \\
\text { hospital equipment was quite high. } \\
\text { - Hospital hot water energy use was high due } \\
\text { to the clinical requirements. }\end{array}$ & $\begin{array}{l}\text { - A low efficiency, old, steam-based central } \\
\text { heating network serves the building. A new } \\
\text { CHP plant was to be installed for the entire } \\
\text { facility rather than just for the new building } \\
\text { to maximise savings. However, this has not } \\
\text { happened yet. } \\
\text { - Fans and pumps are used to provide close } \\
\text { control to the indoor environment. Demand } \\
\text { control ventilation could have been used } \\
\text { more effectively. }\end{array}$ \\
\hline $\begin{array}{l}\text { Apartment } \\
\text { Block }\end{array}$ & $\begin{array}{l}\text { - Occupants had full control over heating } \\
\text { system \& Mechanical Ventilation with Heat } \\
\text { Recovery (MVHR), determining their set-points } \\
\text { and operations. } \\
\text { - Occupancy of the individual flat is very } \\
\text { uncertain to determine, specially holidays. } \\
\text { - CO } 2 \text { monitoring show possible lack of } \\
\text { occupancy during school holiday times. } \\
\text { - There are instances where it is evident that } \\
\text { during summer, the windows were opened for } \\
\text { enhanced ventilation, while the heating system } \\
\text { was still operational. }\end{array}$ & $\begin{array}{l}\text { - Maintaining of filters in the de-centralised } \\
\text { Mechanical Ventilation with Heat Recovery } \\
\text { (MVHR) systems was left to the occupants } \\
\text { and therefore there were maintenance } \\
\text { issues (e.g. dirty filters) in most flats. } \\
\text { - Cold bridging was evident around the } \\
\text { balconies and through air leakage from the } \\
\text { doors. } \\
\text { - Efficiency of the district heating network, } \\
\text { estimated at } 91 \% \text { in design calculations, } \\
\text { was around } 50 \% \text { in practice. }\end{array}$ \\
\hline
\end{tabular}

Building

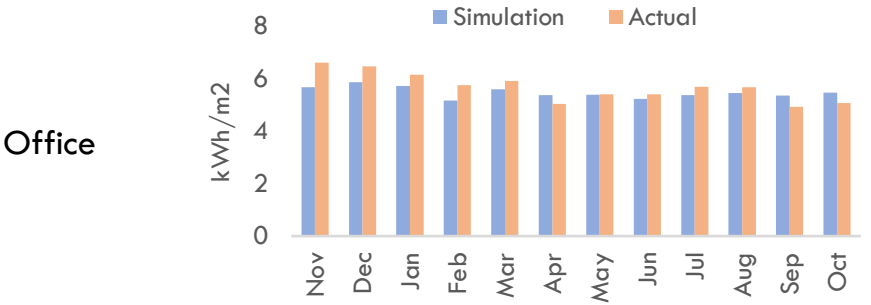

Gas Use

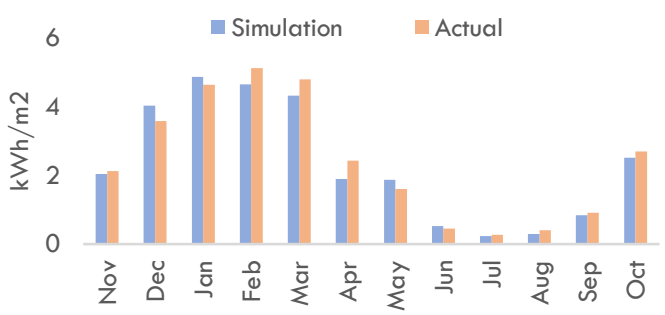




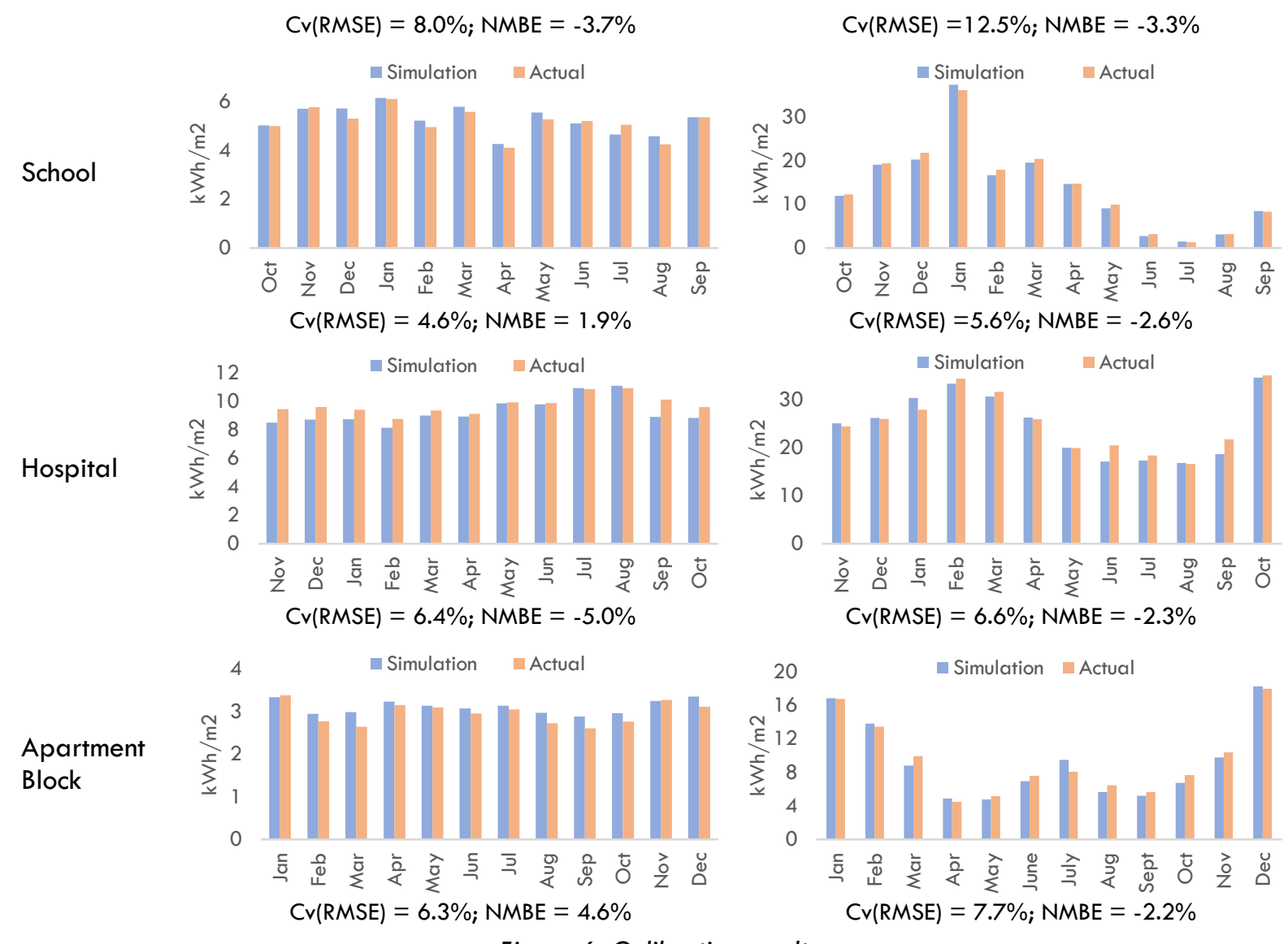

Figure 6: Calibration results

To ensure the calibrated model reasonably reflected the actual building's operation, Figure 7 shows the temperature trends for typical days for a few monitored spaces in all the buildings. The simulated temperatures closely follow the measured air temperature, except the few instances where there are some deviations. For example, there is a dip in simulated temperatures in the office during the weekends. Similarly, overnight simulated temperatures over the weekend in the school are lower than the monitored values. Also, the modelled radiant temperature is sometimes less than the modelled air temperature in some building types due to a poor thermal envelope and the subsequent heat losses. For example, in the case of the office, thermal imaging of the envelope revealed leakage through poorly sealed vents and at construction junctions (Figure 8). Similarly, in the school significant thermal bypasses around insulation was observed and verified with Uvalue measurements (Figure 9). These are consistent with the issues identified in Table 5. 

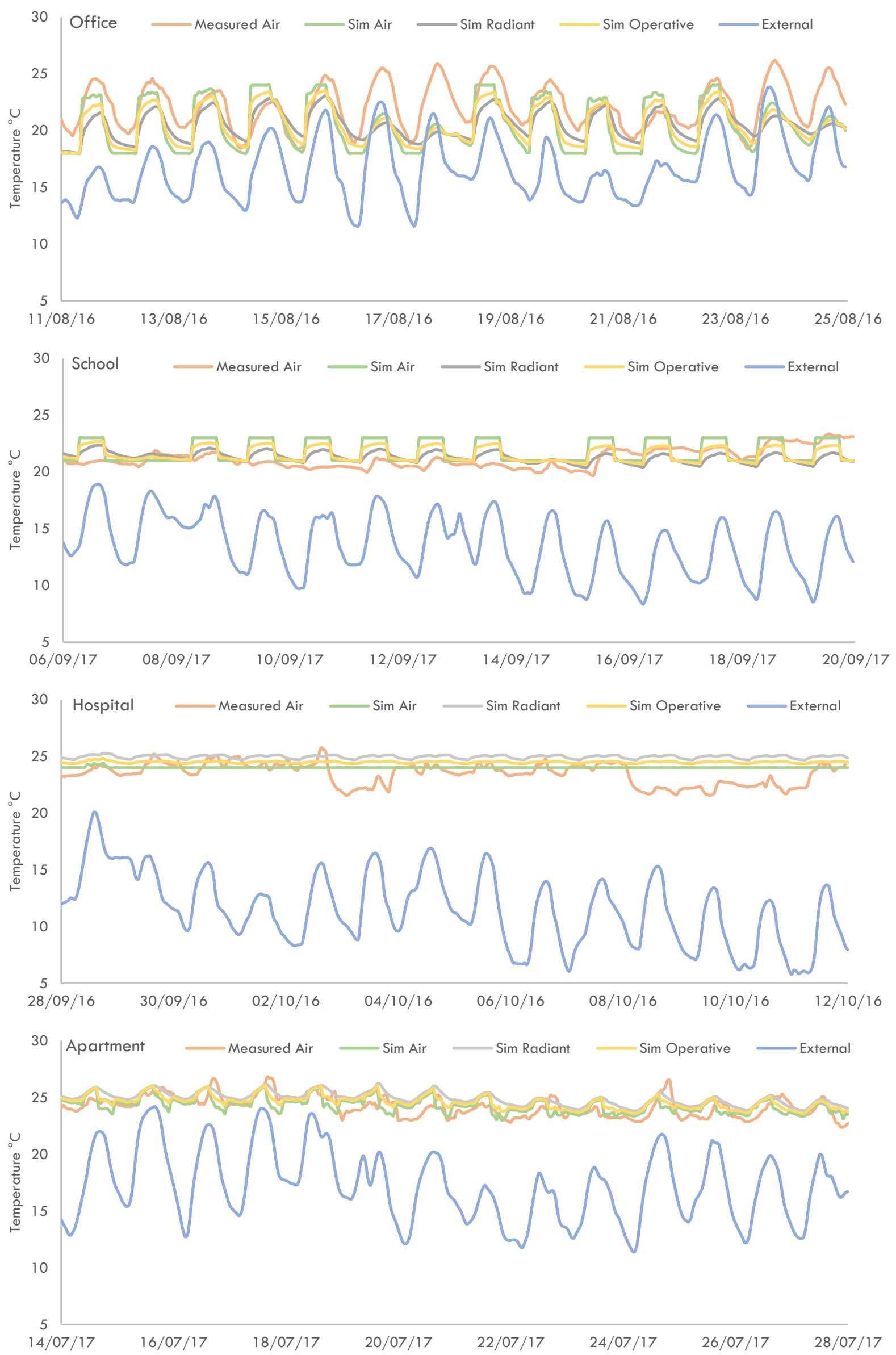

Figure 7: Hourly simulated and measured temperature profiles for typical days 

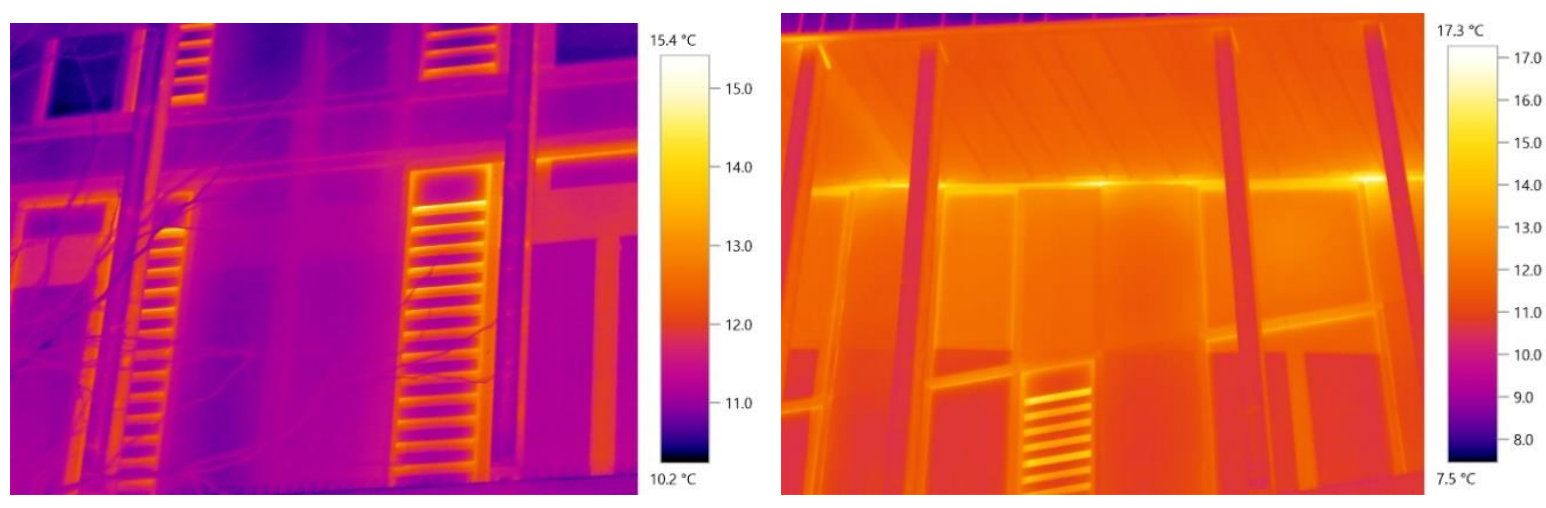

Figure 8: Heat loss from the doors installed behind natural vent louvers in closed position (left), and at construction junctions in the office building
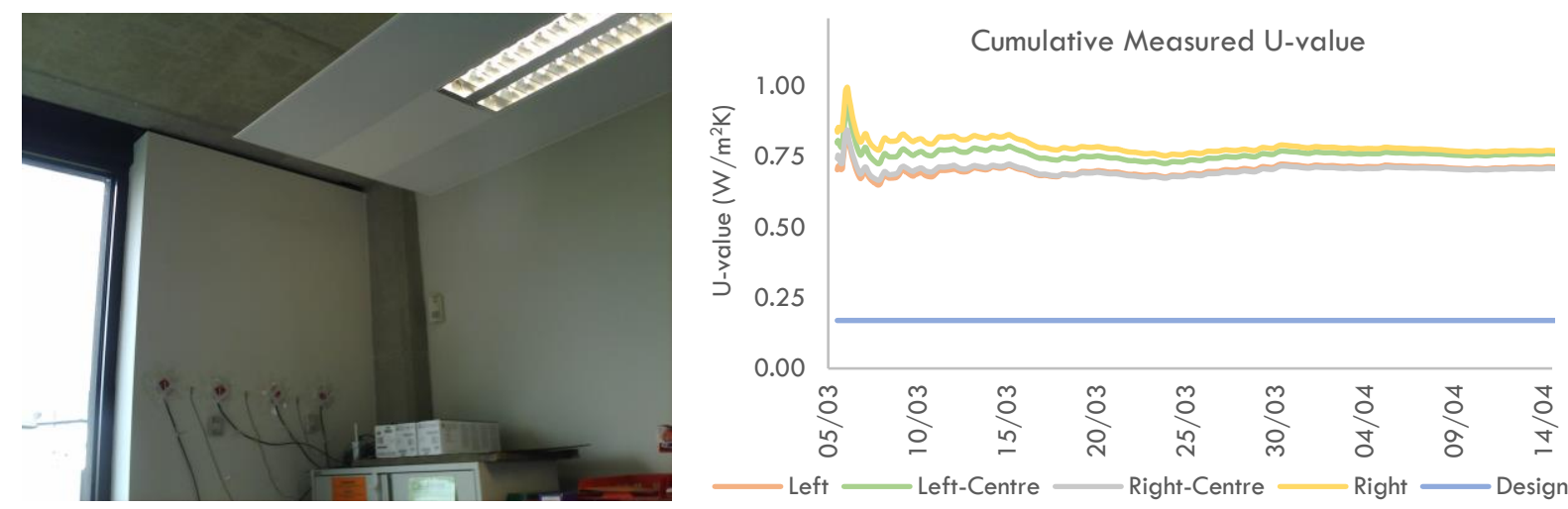

Figure 9: In-situ U-value measurements on a single north-facing section of the facade in the school building The deviations observed reduce over the longer periods. More fine tuning of the calibrated model, at high resolution, can match these deviations but in the context of monthly calibration for assessing the causes of the performance gap, the current accuracy is deemed sufficient. Overall MAE and RMSE for the hourly temperatures in Figure 7 are less than $1^{\circ} \mathrm{C}$ and less than $1.5^{\circ} \mathrm{C}$ respectively.

\subsection{Operational baseline and the actual gap}

To quantify the performance gap due to technical issues, all the technical issues that were identified in Table 5 were reverted to their design intents according to what was captured during data collection stage. In other words, the technical characteristics of the building were converted back to those intended in the design stage (1B and 1C in Figure 3). For example, in the school building, the $U$ value measured as $0.78 \mathrm{~W} / \mathrm{m}^{2} \mathrm{~K}$ and used in the calibrated model, was reverted to $0.17 \mathrm{~W} / \mathrm{m}^{2} \mathrm{~K}$ as used in the design specification and design model. Figure 10 shows the new operational baselines and they are compared against the design predictions and the actual gap, as explained in Figure 2. In all buildings, except the office, the estimate of compliance calculations of energy use is much lower than the design performance. In the office, due to the performance contracting procurement route, along with the compliance calculations (which were done as per regulatory requirements), design estimates were separately calculated using realistic operational schedules and 
specifications. This difference is also the reason of the apparent overestimation of the compliance calculation results in the office building when compared to other projections.

Office

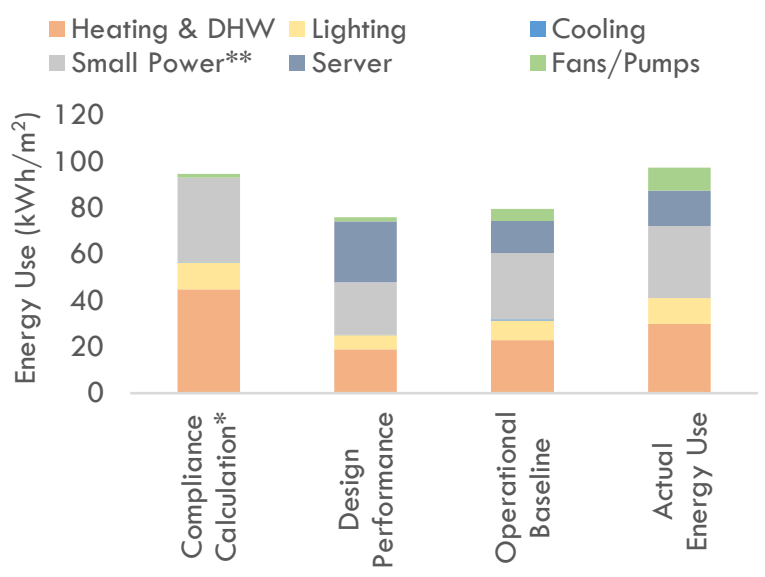

* Compliance calculation, not used for design projections;

** In Actual Energy Use, Small Power includes Cooling.

\section{Hospital}

$$
\begin{aligned}
& \text { ก } 450 \\
& \text { है } 400 \\
& \text { ₹ } 350 \\
& \text { 至 } 300 \\
& 250 \\
& \text { ๑ } 200 \\
& >150 \\
& \text { 흔 } 100 \\
& \text { जँ } 50
\end{aligned}
$$$$
\text { - Heating \& DHW Lighting }
$$$$
\text { Small Power } \quad \text { Server* }
$$

$$
\begin{aligned}
& \text { Cooling } \\
& \text { Fans/Pumps }
\end{aligned}
$$

School

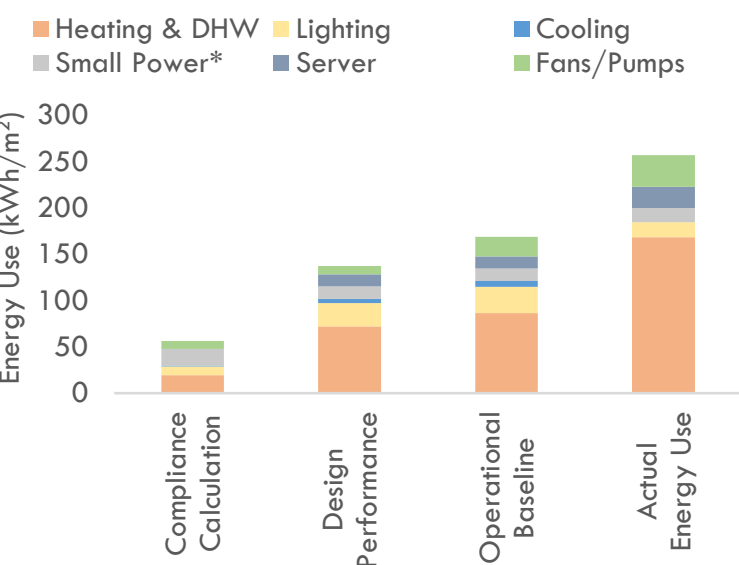

*In Compliance Calculation, Small Power includes Server and in Actual Energy Use, Small Power includes Cooling

\section{Apartment Block}

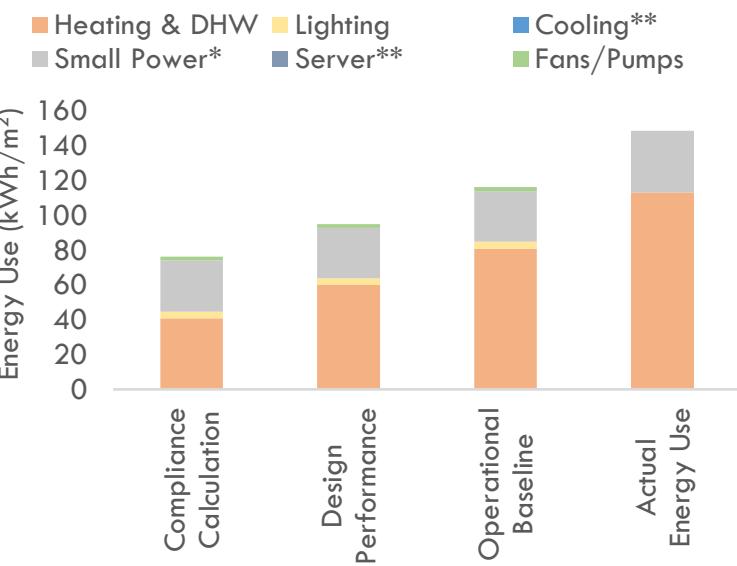

* In Actual Energy Use, Small Power includes Fans/Pumps \& Lighting; ${ }^{* *}$ Cooling \& Server are not present in the building *Server is not present in the building

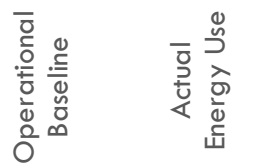

*** (All graphs) Small power use, while used in calculations is not reported in compliance calculations in the UK, however they have been reported here for a more meaningful comparison against other results.

Figure 10: Technical Performance Gap

Further analysis of the calculations and performance gaps helps to understand the effect of the issues identified in Table 5 on the overall performance. The difference between the operational baseline and the actual energy use is the performance gap due to technical issues, such as the sharp increase in the heating energy use in the school, the hospital and the apartment being primarily due to system issues or poor maintenance. The only case where there was a noticeable gap due to operational changes was in the apartments due to the high level of control that the occupants have on the operations and their variable usage patterns. On the other hand, the hospital design performance is higher than the operational baseline because the estimates for equipment loads and their use, assumed as per regulatory standards, is much higher than that in the building. 


\section{$\underline{5.0 \text { Discussion }}$}

Many common themes and lessons were identified by analysing the buildings' performance. While drawn from individual cases, these findings are supportive of other similar studies (Burman, 2016; Palmer, et al., $2016 a$; Palmer, et al., 2016b). Therefore, the issues identified are considered to be endemic in the industry and are likely to have applicability in other buildings and across the construction sector.

\section{$\underline{5.1 \text { Cross-sectoral performance issues }}$}

Design stage energy projections: The use of regulatory compliance calculations as the design stage predicted performance may underestimate the actual energy use significantly and lead to a perceived gap (Figure 10: the school, the hospital and the apartment block). To avoid this perceived gap, realistic estimation of energy use at the design stage should be mandatory, calculated as per CIBSE TM54 guidelines or other equivalent protocols. This was carried out in the office building where, a contractually mandated performance target to beat the operational benchmarks was the driver for the design team to undertake realistic calculations.

Performance targets and contractual accountability: Due to a strict operational performance target the overall energy use in the office is not just lower than other building types (Figure 10), but also much lower than the benchmarks within its building category. Performance contracting, integrated within a Soft Landings framework, guaranteed the involvement of the contractor and the designers after the handover to fine tune the building operations and fix issues related to design, construction and commissioning. Increased accountability also leads to robust construction quality checks, thereby mitigating issues such as significantly high U-values seen in the school or cold bridges in the apartment block. One of the challenges in performance contracting is the contractual period, which might determine the sustainability measures used. Also, if key sustainability measures that are beneficial in the longer term are not safeguarded from the start, some may be value engineered out within the construction process. Another challenge is to objectively define the targets and the metric to use, i.e. ensuring that the metrics are in alignment with the actual intent. For example, targeting net carbon emissions may result in a different approach than when the focus is on energy use only. Also, in certain building types, such as hospitals, current benchmarks have very broad categories. As seen in the case study, within each category the energy demands can vary significantly as per the specialised services provided. In these cases, energy analysis and benchmarking need to look beyond the entire building and consider departments or other sub-spaces as the unit of analysis.

Uncertainties in building use: Operational uncertainties also affect the design prediction. Occupant behaviour is uncertain and has a significant effect in cases when occupants have high degree of control, such as in apartments. Small events can affect a flat's energy use significantly, such as a sharp drop seen in energy 
use during holiday time in the case study flat. This is also a reason for the wide variation in the energy use of the 98 flats (Figure 5) within the apartment block. In most large non-domestic buildings, the services are controlled centrally by building managers, limiting the occupant effect to manual overriding of zone thermostats and operation of windows. To address them, sensitivity and scenario analysis can be used to take informed design decisions and operational safeguards regarding the most important factors.

Transitionally/seasonally occupied buildings and changing user patterns: Contrary to design assumptions, nowadays schools have higher space-time utilisation. Beyond the regular school hours, the case study school had partial occupancy for evening/holiday schools and out-of-hours extracurricular activities. However, the building services were not tuned for low occupancy, out-of-hours running. A centralised system design (one control and sensor for multiple zones) led to multiple spaces (including the unoccupied ones) being conditioned during the transitional occupancy times. The ability to hydraulically isolate the unoccupied areas and use decentralized controls is beneficial in these scenarios. Flexible space use, including hot desking in offices, is another practice used to manage transitional occupancy. In the office building, hot-desking was implemented in conjunction with hydraulic isolation. It was assumed that during low occupancy times all the users could work in one part of the building, keeping the rest of the building shut. However, due to the departmental nature of the occupant organisation, it was not achieved in practice. Regular users occupied their usual desks within the part of building where their department was located.

Use of new and innovative low-carbon technologies: The technologies used across the case studies were partly effective. In the office, the innovative strategy of using free heat from server rooms was not successful due to technical issues. In the school, driven by the local council's intention to use and promote low carbon technologies, a biomass boiler was installed. However, due to the enhanced logistics needed to manage the fuel, the biomass boiler was not operational post-handover. In the hospital too, the new CHP system, agreed at the campus level at design stage, has not been installed due to budgetary constraints. Therefore, while there was an intent, lack of follow-up and checks meant that the intended benefits were not achieved.

Protocols for managing building operations: Some of the performance issues in the case studies were due to sub-optimal operations and irregular maintenance. In the office, delays in resolving issues with sensors and automatic roof vents meant that some of the vents were either left open or remained closed. In the apartments, management of the Mechanical Ventilation with Heat Recovery (MVHR) system and replacement of filters was the responsibility of individual occupants. However, the occupants were either not aware of it or did not understand the need/requirement of regularly changing them. An effective building operation and management strategy envisaged in design and incorporated at handover would help manage these issues. 


\subsection{Going beyond energy, understating the unintended IEQ underperformance}

In all case study buildings, energy performance was the only specific quantified performance objective. There was no effective metering, monitoring, and reporting strategy for any of the IEQ parameters. However as discussed earlier, lower energy use and better IEQ can be divergent objectives. The temperature, $\mathrm{CO}_{2}, \mathrm{NO}_{2}$ and $P M_{2.5}$ measurements provided insights into the IEQ and suggested their potential energy related implications. Some of the unintended IEQ performance issues, shown in Figure 11, across the case studies are:

- The indoor $\mathrm{CO}_{2}$ concentrations in the office building reached above $2500 \mathrm{ppm}$ due to sensor malfunctioning and also due to the closing of roof vents in winter to avoid cold drafts due to stack effect and to maintain users' thermal comfort. This exceeds the IDA Class II levels for office spaces (CIBSE, 2015).

- The temperature measurements in the school exceed the maximum temperature threshold of $26^{\circ} \mathrm{C}$ (CIBSE, 2013a), because of the airtight envelope and inadequate operable windows in a south facing zone (high solar exposure), lacking solar controls (blinds/shades).

- Located in a congested urban area, there was the lack of measures against ambient $\mathrm{NO}_{2}$ in the hospital building. Indoor $\mathrm{NO}_{2}$ levels recorded in a ward very closely followed the external levels. These recordings were often above the WHO annual mean threshold of $40 \mu \mathrm{g} / \mathrm{m}^{3}(\mathrm{WHO}, 2018)$. This suggests a potential risk of exposure to more than WHO recommended levels if external air remains polluted for prolonged periods. Advanced chemical filtration (such as activated carbon) and controls that consider the balance between requirement for fresh air and protection from outdoor sources of pollution could provide a healthier environment and at the same time save energy.

- Similar air quality issues were seen in the mechanically ventilated apartment block, PM2.5 levels in the flat are close to external levels with some spikes due to internal sources. However, they were frequently higher than WHO annual mean limit of $10 \mu \mathrm{g} / \mathrm{m}^{3}$ (WHO, 2018). The flats used G3 filters, however, as ambient $\mathrm{PM}_{2.5}$ levels are typical for London, use of high-grade filtration (F type filters), while slightly increasing electricity use, will help reduce $\mathrm{PM}_{2.5}$ levels.

These show potential conflicts within IEQ objectives and between energy and IEQ, especially in new lowenergy buildings constructed in polluted urban areas. This is primarily because during operations, unlike energy, IEQ performance is not an explicit target and therefore is not a focus for building monitoring \& finetuning. In some instances, where maintaining better IEQ might result in slightly increased energy use, the energy use increase needs to be offset elsewhere. 
Office

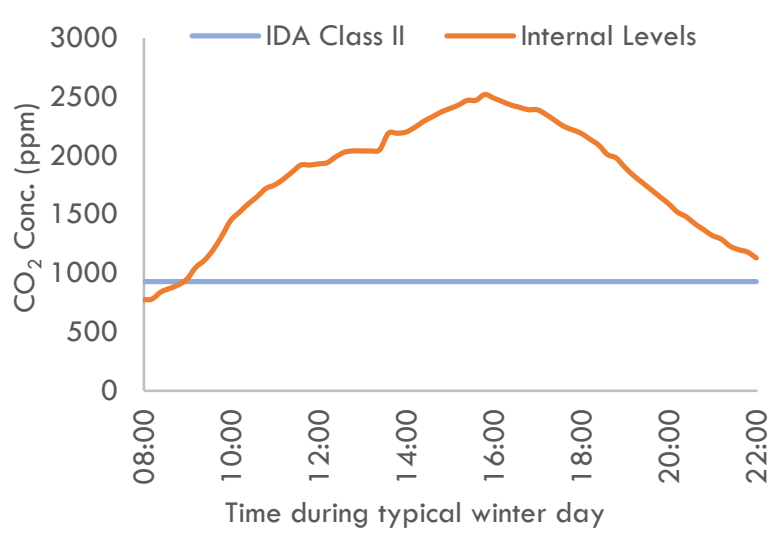

Hospital

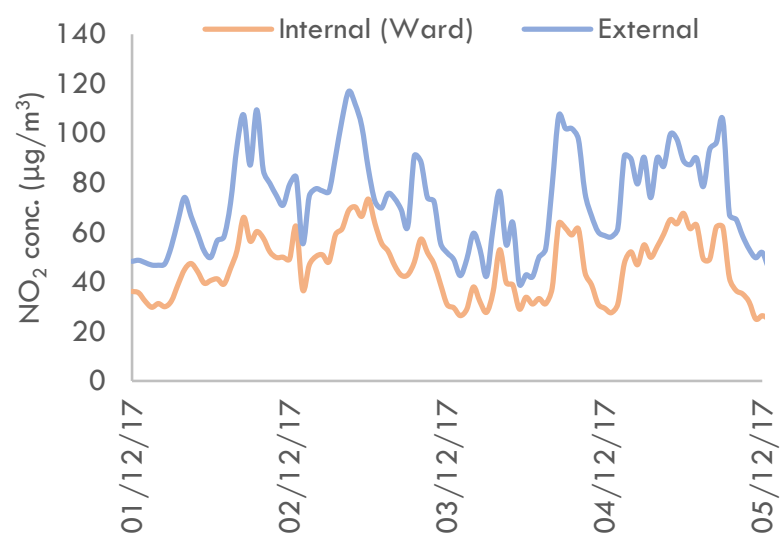

School

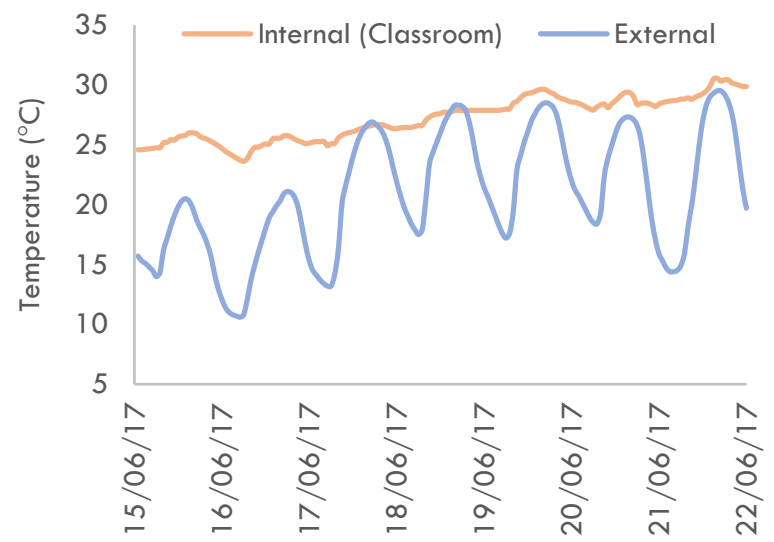

Apartment Block

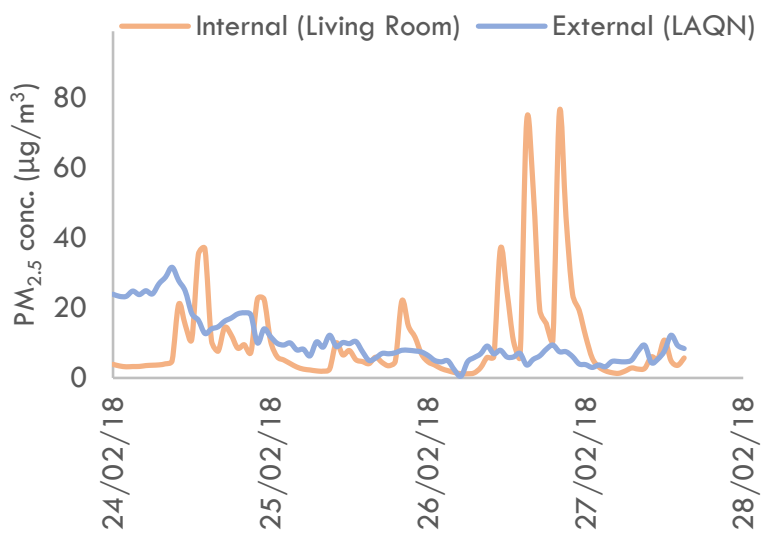

Figure 11: Unintended IEQ issues

\section{$\underline{5.3 \text { Reflections on model calibration challenges and its validation }}$}

Beyond the known issues of approximations and simplifications in simulation models and operational uncertainties, data availability and its quality determine the confidence in calibration results. Disaggregated (end-use and spatial) energy use data is helpful in calibrating at smaller sub-system levels and identifying typical patterns easily. The more granular the data the better it is; however, practicalities of metering can sometimes make it difficult to obtain granular data.

Onsite observations during audits help in verifying many of the design aspects, but it can sometimes be challenging due to factors such as access restrictions in sensitive hospital areas. Discussions with building users and facility managers not only helps in understanding of building usage but also can identify unique events, point towards problem areas and validate any inferences drawn from the data trends. Their inputs are required in the procedural evidence-based calibration method, which needs to be followed, when a calibrated model is used for the performance gap identification. In other words, the fine tuning of the inputs in the base model should be based on observed trends only. 
In case the calibration criteria are not met after all the evidence-based changes, further fine tuning of inputs must be based on engineering judgement but within reasonable ranges, as numerous solutions could generate a calibrated model. However, inferences drawn as performance gap causes should be limited to evidencebased findings. Another way to increase confidence in the calibrated model is to go beyond the current statistical model validation criteria used. More robust validation checks should include examination against other dependent results such as temperatures in typical spaces. This examination ensures that the calibration model not just matches the actual energy performance but other physical parameters as well.

\subsection{Application of the current approach}

This process, aimed at early stages of post occupancy can be easily integrated within the existing project procurement routes that focus on operational performance outcomes such as Soft Landings (Way, et al., 2009). For example, the office building covered in this paper was procured within a Soft Landings Framework.

Most of the processes during design and construction in the Soft Landings run alongside normal procurement practices without much duplication and extra work. The only elements that require additional effort are aftercare activities needed during the initial years of operation, where the approach presented in this paper could be integrated. Depending on the complexity of the project, the cost of these activities can be estimated at around $0.1 \%-0.25 \%$ of total contract value (BSIRA, 2012; Morris, 2017). The extra effort and resources required for integrating the Soft Landings framework or other similar frameworks is minimal and can usually get paid back swiftly because of the reduced building operating costs.

\subsection{Conclusions}

This detailed analysis of the performance gap across multiple buildings provides insights into the performance issues applicable across the UK building sector. Identifying and verifying performance issues using evidencebased model calibration is a novel and robust approach to increase the likelihood that all key issues are found. The calibrated model, when validated statistically for energy use and also for dependent parameters such as space temperatures, ensures that it could be reasonably used for assessing deviations from the design intents. Using this simulation-based approach enables a systematic identification and classification of the root causes of the performance gap, which would not have been possible otherwise.

Root causes identified across the case-studies were due to three factors, (i) a perceived gap due to use of inappropriate design-stage calculation methods, (ii) technical issues with the building, its systems and their operations, and (iii) operational changes that the building has gone through in order to meet its functional requirements. While the first can be dealt by improving industry practices and the third is a change brought 
by necessity, the gap due to technical issues require attention and correction to ensure that the building functions most optimally.

The technical issues identified across the case studies were either due to design errors, improper construction and installation, poor commissioning or due to issues with the low-carbon technologies. It was observed that long term involvement and responsibility for the performance given to the design and construction teams are effective in lowering the performance gaps. Including this approach through performance contracting ensures that after handover the technical issues are addressed, and building is well managed. Additionally, policy measures and safeguards are essential to ensure energy efficiency measures and low carbon systems specified at design stage will be effectively used in practice.

The focus on energy efficiency alone as the performance objective in buildings built with low energy use intentions may lead to unintended IEQ concerns (such as poor IAQ and overheating). Issues observed across the case studies have shown the need to address IEQ simultaneously with energy through better design, advanced operational controls and most importantly incorporate regular IEQ measurements. Including IEQ within the performance contracting framework for energy will help address the trade-offs that happen during operational stage and the unintended health consequences to the occupants.

\section{Acknowledgements}

The authors gratefully acknowledge the financial support by UCL Overseas Research Scholarships (UCL-ORS), DesignBuilder Software Ltd., Innovate UK KTP project (Partnership number:11615) and The 'Total Performance' of Low Carbon Buildings in China and the UK ('TOP') project funded by EPSRC (EP/N009703/1).

\section{References}

Abadie, M. \& Wargocki, P., 2016. Indoor Air Quality Design and Control in Low-energy Residential Buildings, Subtask 1, Defining the metrics, s.l.: IEA EBC Annex 68.

Ahmad, M. \& Culp, C. H., 2006. Uncalibrated Building Energy Simulation Modeling Results. HVAC\&R Research, 12(4), pp. $1141-1155$.

Andre, P. et al., 2008. From model validation to production of reference simulations: how to increase reliability and applicability of building and HVAC simulation models. Build. Serv. Eng. Res. Technol., 29(1), pp. $61-72$.

AQEG, 2004. Nitrogen Dioxide in the United Kingdom: Summary, London: Defra.

AQEG, 2005. Particulate Matter in the UK: Summary, London: Defra.

ASHRAE, 2014. Measurement of energy, demand and water savings - ASHRAE Guidelines 14-2014, Atlanta: American Society of Heating, Refrigerating and Air-Conditioning Engineers (ASHRAE).

Azar, E. \& Menassa, C., 2012. Sensitivity of Energy Simulation Models to Occupancy Related Parameters in Commercial Buildings. s.l., Construction Research Congress 2012. 
Bannister, P., 2009. Why good buildings go bad while some are just born that way. s.l., Ecolibrium.

Batterman, S., 2017. Review and Extension of CO2-Based Methods to Determine Ventilation Rates with Application to School Classrooms. International Journal of Environmental Research and Public Health, 14(2), p. 145.

BEIS, 2016. Building Energy Efficiency Survey 2014-15 (BEES) Overarching Report, London: Department for Business, Energy \& Industrial Strategy, HM Government.

Beizaee, A., 2016. Measuring and Modelling the Energy Demand Reduction Potential of Using Zonal Space Heating Control in a UK Home. A Doctoral Thesis, Loughborough, UK: Loughborough University.Bertagnolio, S., Randaxhe, F. \& Lemort, V., 2012 . Evidence-based calibration of a building energy simulation model : Application to an office building in Belgium. Manchester ", Twelfth International Conference for Enhanced Building Operations.

Booten, C. \& Tabares-Velasco, P. C., 2012. Using EnergyPlus to Simulate the Dynamic Response of a Residential Building to Advanced Cooling Strategies. Boulder, Colorado, 2nd International Conference on Building Energy and Environment.

Bordass, B., Cohen, R. \& Field, J., 2004. Energy Performance of Non-Domestic Buildings - Closing the Credibility Gap. Frankfurt, IEECB'04 Building Performance Congress.

Bordass, B., Cohen, R., Standeven, M. \& Leaman, A., 2001 a. Assessing building performance in use 3: energy performance of the PROBE buildings. Building Research \& Information, 29(2), pp. 114-128.

Bordass, B., Leaman, A. \& Ruyssevelt, P., 2001 b. Assessing building performance in use 5: conclusions and implications. Building Research \& Information, 29(2), pp. 144-157.

BRECSU, 1996. Energy consumption guide 72: Energy consumption in hospitals, Watford, UK: Building Research Energy Conservation Support Unit (BRECSU).

BSIRA, 2012 . Soft Landings procurement and budgets. [Online]

Available at: https://www.bsria.com/uk/news/article/soft-landings-procurement-and-budgets/

[Accessed 1304 2020].

Burman, E., 2016. Assessing the Operational Performance of Educational Buildings against Design Expectations - A Case Study Approach. Doctoral Thesis, London: UCL (University College London).

Burman, E., Mumovic, D. \& Kimpian, J., 2014. Towards measurement and verification of energy performance under the framework of the European directive for energy performance of buildings. Energy, Volume 77, pp. 153-163.

Carbon Trust, 2012. Closing the Gap - Lesson Learned on Realising the Potential of Low Carbon Building Design, London: The Carbon Trust.

Chai, T. \& Draxler, R. R., 2014. Root mean square error (RMSE) or mean absolute error (MAE)? Arguments against avoiding RMSE in the literature. Geoscientific Model Development, Volume 7, pp. 1247-1250.

CIBSE, 2012 . CIBSE Guide F: Energy efficiency in buildings, London: The Chartered Institution of Building Services Engineers.

CIBSE, 2013a. TM52: The Limits of Thermal Comfort: Avoiding Overheating in European Buildings, London: The Chartered Institution of Building Services Engineers (CIBSE).

CIBSE, 2013b. TM54: Evaluating Operational Energy Performance of Buildings at the Design Stage, London: The Chartered Institution of Building Services Engineers (CIBSE).

CIBSE, 2015. CIBSE Guide A: Environmental design, London: The Chartered Institution of Building Services Engineers.

Council Directive, 2018. Directive (EU) 2018/844 of the European Parliament and of the Council of 30 May 2018 amending Directive 2010/31/EU on the energy performance of buildings and Directive 
2012/27/EU on energy efficiency (Text with EEA relevance). Official Journal of the European Union, 156(19.6.2018), pp. 75-91.

DCLG, 2017. A guide to Energy Performance Certificates for the construction, sale and let of non-dwellings, London: UK Department for Communities and Local Government.

de Wilde, P., 2014. The gap between predicted and measured energy performance of buildings: A framework for investigation. Automation in Construction, Volume 41, pp. 40-49.

de Wilde, P. \& Jones, R., 2014. The building energy performance gap: up close and personal. Dublin, CIBSE ASHRAE Technical Symposium 2014.

DECC, 2018 . Energy Consumption in the UK ( 2018 ) Chapter 5: Service sector energy consumption in the UK between 1970 and 2017, London, UK: Department of Energy \& Climate Change, UK.

DesignBuilder Software Ltd., 2019. Climate Analytics. [Online]

Available at: https://analytics.designbuilder.co.uk/

[Accessed 12112019$]$.

DesignBuillder Software Ltd., 2019. DesignBuilder V6, Stroud: DesignBuillder Software Ltd..

EVO, 2016. Core Concepts: International Performance Measurement and Verification Protocol, Washington DC: Efficiency Valuation Organization.

Fabbri, K. \& Tronchin, L., 2015. Indoor Environmental Quality in Low Energy Buildings. Energy Procedia, Volume 78, pp. 2778-2783.

Garrett, A. \& New, J., 2016. Suitability of ASHRAE guideline 14 metrics for calibration. ASHRAE Transactions, 122(1), p. 469+.

Guyon, G., 1997. Role of the model user in results obtained from simulation software program. Prague, 6th International Building Performance Simulation Association Conference.

Haldi, F. \& Robinson, D., 2008. On the behaviour and adaptation of office occupants. Building and Environment, 43(12), p. 2163-2177.

HM Government, 2019. The Climate Change Act 2008 (2050 Target Amendment) Order 2019, London: HM Government.

IEA, 2017. Energy Technology Perspectives 2017: Catalyzing Energy Technology Transformations, Paris: International Energy Agency.

Jain, N. et al., 2017. Improving the Energy Performance Contracting Process using Building Performance Simulation: Lessons Learnt from a Post Occupancy Investigation of a Case Study in the UK. San Francisco, USA, Proceedings of the 15th IBPSA (International Building Performance Simulation Association) Conference, Aug. 7-9, 2017.

Jain, N. et al., 2018. Comparative Analysis of Protocols Used in Measurement and Verification of Energy Performance: Dealing with Practical Issues of Data Availability and Granularity in a UK School Building. Cambridge, UK, Proceedings of BSO 2018: 4th Building Simulation and Optimization Conference, Cambridge, UK: $11-12$ September 2018.

Judkoff, R., Wortman, D., O'Doherty, B. \& Burch, J., 2008. A Methodology for Validating Building Energy Analysis Simulations, Colorado: National Renewable Energy Laboratory.

Kapalo, P., 2013. Analysis of ventilation rate and concentration of carbon dioxide in the office. s.l.:Technical University of Kosice, Slovakia.

Kimpian, J. \& Chisholm, S., 2011 . Tracking Design and Actual Energy Use: CarbonBuzz, an RIBA CIBSE platform. Louvain-la-Neuve, International conference on Passive and Low Energy Architecture (PLEA).

Larsen, T. S., Daniels, O. \& Jensen, R. L., 2012 2. Evaluation of the indoor environment in 8 Danish passive houses. Trondheim, Passivhus Nordern. 
Logue, J. M., McKone, T. E., Sherman, M. H. \& Singer, B. C., 2011 . Hazard assessment of chemical air contaminants measured in residences. Indoor Air, 21 (2), pp. 92-109.

Maivel, M., Kurnitski, J. \& Kalamees, T., 2015. Field survey of overheating problems in Estonian apartment buildings. Architectural Science Review, 58(1).

Martani, C. et al., 2012 . ENERNET: Studying the dynamic relationship between building occupancy and energy consumption. Energy and Buildings, Volume 47, pp. 584-591.

Menezes, A. C., Cripps, A., Bouchlaghem, D. \& Buswell, R., 2012. Predicted vs. actual energy performance of non-domestic buildings: Using post-occupancy evaluation data to reduce the performance gap. Applied Energy, Volume 97, pp. 355-364.

Moore, D. S., Notz, W. I. \& \& Flinger, M. A., 2015. The basic practice of statistics. 7th ed. New York: WH Freeman.

Morgensterna, P. et al., 2016. Benchmarking acute hospitals: Composite electricity targets based ondepartmental consumption intensities?. Energy and Buildings, Volume 118, pp. 277-290.

Morris, N., 2017. RIBA calls on government to commit to POE. [Online]

Available at: https://www.architecture.com/knowledge-and-resources/knowledge-landing-page/ribacalls-on-government-to-commit-to-poe

[Accessed 0105 2020].

Neymark, J. et al., 2002. Applying the building energy simulation test (BESTEST) diagnostic method to verification of space conditioning equipment models used in whole-building energy simulation programs. Energy and Buildings, 34(9), pp. 917-931.

Norford, L. K., Socolow, R. H., Hsieh, E. S. \& Spadaro, G. V., 1994. Two-to-one discrepancy between measured and predicted performance of a 'low-energy' office building: insights from a reconciliation based on the DOE-2 model. Energy and Buildings, $21(2)$, pp. 121-131.

ONS, 2011 . Nomis official labour market statistics. [Online]

Available at: https://www.nomisweb.co.uk/

[Accessed 0801 2020].

Palmer, J., Godoy-Shimizu, D., Tillson, A. \& Mawditt, I., 2016 a. Building Performance Evaluation Programme: Findings from domestic projects; Making reality match design, Swindon: Innovate UK.

Palmer, J., Terry, N. \& Armitage, P., 2016 b. Building Performance Evaluation Programme, Findings from NonDomestic Projects, London: Innovate UK.

Pang, X., Wetter, M., Bhattacharya, P. \& Haves, P., 2012. A framework for simulation-based real-time whole building performance assessment. Building and Environment, Volume 54, pp. 100-108.

Parsons, P., 2014. Determining Infiltration Rates and Predicting Building Occupancy Using CO2 Concentration Curves. Journal of Energy, Volume 2014, p. 6 pages.

Petersen, S. \& Hviid, C. A., 2012. The European Energy Performance of Buildings Directive: Comparison of calculated and actual energy use in a Danish office building. Loughborough, Building Simulation and Optimization Conference.

Phillips, T. J. \& Levin, H., 2015. Indoor environmental quality research needs for low-energy homes. Science and Technology for the Built Environment, $21(1)$, pp. 80-90.

Piette, M. A. et al., 1994. Over the energy edge: results from a seven year new commercial buildings research and demonstration project, Berkeley: LBNL.

Raftery, P., Keane, M. \& O’Donnell, J., 2011 . Calibrating whole building energy models: An evidencebased methodology. Energy and Buildings, Volume 43, p. 2356-2364. 
Reddy, T. A. \& Maor, I., 2006. Procedures for Reconciling Computer-Calculated Results With Measured Energy Data ASHRAE Research Project 1051 - RP, Philadelphia: Drexel University.

Roberti, F., Oberegger, U. F. \& Gasparella, A., 2015. Calibrating historic building energy models to hourly indoor air and surface temperatures: Methodology and case study. Energy and Buildings, 108(1), pp. 236243.

Royapoor, M. \& Roskilly, T., 2015. Building model calibration using energy and environmental data. Energy and Buildings, 94(1), pp. 109-120.

Ruiz, G. R. \& Bandera, C. F., 2017. Validation of Calibrated Energy Models: Common Errors. Energies, 10(10), p. 1587.

Ruiz, G. R., Bandera, C. F., Temes, T. G.-A. \& Gutierrez, A. S.-O., 2016. Genetic algorithm for building envelope calibration. Applied Energy, Volume 168, pp. 691-705.

Samuelson, H. W., Ghorayshi, A. \& Reinhart, C. F., 2014. Post-Occupancy Evaluation and Partial-Calibration of 18 Design-Phase Energy Models. Atlanta, ASHRAE/IBPSA-USA Building Simulation Conference.

Shrubsole, C. et al., 2018. Bridging the gap: The need for a systems thinking approach in understanding and addressing energy and environmental performance in buildings. Indoor and Built Environment, 28(1), pp. 100-117.

Tuohy, P. G. \& Murphy, G. B., 2015. Are current design processes and policies delivering comfortable low carbon buildings?. Architectural Science Review, 58(1), pp. 39-46.

Turner, C. \& Frankel, M., 2008. Energy Performance of LEED for New Construction Buildings, Vancouver: New Buildings Institute (NBI).

van Dronkelaar, C. et al., 2016. A Review of the Energy Performance Gap and Its Underlying Causes in Non-Domestic Buildings. Frontiers in Mechanical Engineering, Volume 1, p. 17.

Wang, S., Yan, C. \& Xiao, F., 2012 . Quantitative energy performance assessment methods for existing buildings. Energy and Buildings, Volume 55, pp. 873-888.

Way, M., Bordass, B., Leaman, A. \& Bunn, R., 2009. The Soft Landings Framework, London: Building Services Research \& Information Association and Usable Build Trust.

WHO, 2018. Ambient (outdoor) air pollution. [Online]

Available at: https://www.who.int/news-room/fact-sheets/detail/ambient-(outdoor)-air-quality-and-health [Accessed 0105 2020].

Wingfield, J. et al., 2013. Centenary Quay Fabric and District Heating performance Study, London: Innovate UK.

ZCH, 2014. Closing the gap between design and as-built performance, London: Zero Carbon Hub. 